\title{
Macrofossil evidence of alder ( Alnus sp.) in Britain early in the Late Glacial Interstadial: implications for the northern cryptic refugia debate
}

Article

Accepted Version

Young, D. ORCID: https://orcid.org/0000-0002-8700-8704, Green, C. P., Batchelor, C. R., Austin, P., Elias, S. A., Athersuch, J. and Lincoln, P. (2021) Macrofossil evidence of alder ( Alnus sp.) in Britain early in the Late Glacial Interstadial: implications for the northern cryptic refugia debate. Journal of Quaternary Science, 36 (1). pp. 40-55. ISSN 0267-8179 doi: https://doi.org/10.1002/jqs.3258 Available at https://centaur.reading.ac.uk/93829/

It is advisable to refer to the publisher's version if you intend to cite from the work. See Guidance on citing.

Published version at: https://doi.org/10.1002/jqs.3258

To link to this article DOI: http://dx.doi.org/10.1002/jqs.3258

Publisher: Wiley

All outputs in CentAUR are protected by Intellectual Property Rights law, including copyright law. Copyright and IPR is retained by the creators or other copyright holders. Terms and conditions for use of this material are defined in the End User Agreement. 


\section{www.reading.ac.uk/centaur}

\section{CentAUR}

Central Archive at the University of Reading

Reading's research outputs online 


\title{
Macrofossil evidence of alder (Alnus sp.) in Britain early in the Late Glacial Interstadial: Implications for the northern cryptic refugia debate
}

Running title: Evidence for alder in Britain during the Lateglacial Interstadial

\author{
D.S. Young ${ }^{1 *}$, C.P. Green ${ }^{1}$, C.R. Batchelor ${ }^{1}$, P. Austin ${ }^{2}$, S.A. Elias ${ }^{3}$, J. Athersuch ${ }^{4}$ and \\ P. Lincoln ${ }^{1}$ \\ ${ }^{1}$ Quaternary Scientific (QUEST), School of Archaeology, Geography and Environmental
} Science, University of Reading, Whiteknights, Reading, Berkshire, UK

${ }^{2}$ Department of Archaeology, University College London, London, UK

${ }^{3}$ University of Colorado, INSTAAR Campus Box 450 Boulder, CO, USA 80309

417 The Bothy, Ottershaw Park, Chobham Road, Ottershaw, Surrey, UK*

Corresponding Author: Dr Dan Young, d.s.young@reading.ac.uk

\begin{abstract}
Wood macrofossil remains of alder and willow/poplar have been recovered from a sediment sequence in the valley of the Turker Beck in the Vale of Mowbray, North Yorkshire. These remains have yielded radiocarbon dates early in the Devensian Lateglacial (14.7-14k cal a $\mathrm{BP}$ ), equivalent to the early part of the Greenland Interstadial (GI-1e) of the GRIP ice-core record. These are the earliest dates recorded for the presence of alder in the Lateglacial in the British Isles. Associated biological remains have provided a palaeoenvironmental record for this early part of the Greenland Interstadial, generally indicative of open environments dominated by herbaceous taxa on both the wetland and dryland surfaces. However, stands of alder, birch and willow woodland were also present, and indicate the possibility that such tree species survived in cryptic refugia in Britain as elsewhere in northern Europe during the Last Glacial Maximum. The absence of alder pollen at Turker Beck, in a sequence in which its macrofossil remains are relatively abundant, lends support to the view that pollen can be a poor indicator of the presence of tree species in Lateglacial sequences in northern and western Europe.
\end{abstract}

Keywords: Cryptic refugia, Lateglacial Interstadial, palaeoecology, vegetation history, alder

Data availability statement: The data that support the findings of this study are available from the corresponding author upon reasonable request.

*Dr John Athersuch does not currently have an academic affiliation 


\section{Introduction}

\subsection{Introduction}

Palaeoecological investigations have characterised the Last Glacial to Interglacial Transition (LGIT) as a period of abrupt, high amplitude climatic shifts (e.g. Walker et al., 2003; Mayle et al., 1999; Innes et al., 2009; Candy et al., 2016; Wohlfarth et al., 2017). How these shifts affected the distribution of trees and other species has often been debated, with particular reference to the role and distribution of cryptic refugia. Recent studies of the behavior of tree species following the Last Glacial Maximum (LGM) in northern, eastern and central Europe (Stewart \& Lister, 2001; Kullman, 2002; Willis \& van Andel, 2004; Kullman, 2008; Douda et al., 2014) have challenged the paradigm that climate-sensitive plant species became restricted to low-latitude regions during the LGM and have indicated that the spread of trees (and other species) may have involved expansion of small populations from cryptic refugia relatively close to the ice margin, rather than exclusively by northward migration from larger refugia in southern Europe. The discovery of macrofossil remains of tree species close to the former ice front and datable to the period closely following glaciation has contributed significantly to this revised understanding of the role and distribution of refugia, and provides further information on the resilience of wetland forest habitats in the context of global climate change.

In the British Isles there are few sites that preserve a record of environmental conditions in the early part of the Devensian Lateglacial, equivalent to the Bolling Interstadial of the NW European succession and the early part of the Greenland Interstadial (GI-1e) of the GRIP ice-core record (see Rasmussen et al., 2014). Those palaeoenvironmental records that do exist are often poorly dated due to the negative effect of hard water error, particularly in Yorkshire (e.g. Walker et al., 1993; Day, 1996; Gearey, 2008). This paper records a multiproxy investigation of biological remains in the floodplain sediments of the Turker Beck in North Yorkshire $\left(1^{\circ} 24.860^{\prime} \mathrm{W} 4^{\circ} 20.684^{\prime} \mathrm{N}\right)$. The organic material includes macrofossil remains of willow/poplar and alder from which radiocarbon dates have been obtained in the early part of the Devensian Lateglacial (14.7-14.0k cal a BP).

\subsection{Topographical and geological setting}

The Turker Beck is a small stream on the east side of the Vale of Mowbray, rising on the high ground to the east of Northallerton and flowing westward through the town (Figure 1). The British Geological Survey (BGS) (1:50,000 Sheet 42, 1994) shows the Turker Beck valley underlain at the site by 'lacustrine deposits - clay and silt' overlying Devensian glacial deposits of the Vale of York Formation, described as 'clay, sandy, gravelly'. The bedrock beneath the site and underlying the whole of the Turker Beck catchment is the Middle Triassic Mercia Mudstone. During the Devensian LGM, the Vale of Mowbray was occupied by ice which moved southward into the Vale of York to reach a limit south of York. The maximum extent of this ice advance has been dated to between ca. 21.8-24.8k and 19.3$21.7 \mathrm{k}$ cal a BP (Bateman et al., 2008). The deposits of the Vale of York Formation that underlie the Turker Beck site are the product of this glacial advance. Evidence of the succeeding phase of climatic amelioration is preserved at various sites in northern England to the east of the Pennines (see Innes et al., 2009), but there are few sequences reliably dated to earlier than 13k cal a BP (see Table 1). The deposits identified at Turker Beck thus represent one of the earliest sequences of organic sediments dated to the Lateglacial Interstadial in the British Isles from which palaeoenvironmental evidence has been obtained.

\subsection{Previous investigations}

The deposits at Turker Beck were first recorded during archaeological investigations funded by the Environment Agency (Environment Agency, 2013; Rackham \& Clay, 2014). In the 
sediment sequences recorded by Rackham \& Clay (2014; Figure 2), sands and gravels were usually present towards the base, overlying stony clays interpreted as 'boulder clay'. They were generally succeeded by a thin $(<0.5 \mathrm{~m})$ sequence of organic deposits ranging from slightly organic sand to peat. Overlying these organic deposits was a thicker (ca. $0.5 \mathrm{~m}$ ) layer of clay in which the modern soil was developed. The peat was recorded by Rackham \& Clay (2014) only to the south of the present course of the Turker Beck, but was traced there in a W-E transect parallel with the course of the stream over a distance of ca. $120 \mathrm{~m}$. Two radiocarbon dates from the peat suggested a Lateglacial age for the organic deposits; the lower sample yielded a date of $14165-14275 \mathrm{cal}$ a BP (SUERC 49860) and the upper sample (0.16m above the lower sample) a date of 12295-12385 cal a BP (SUERC 49861).

\section{Field and Laboratory investigations}

\subsection{Lithostratigraphy}

In the present investigation, a trench was opened (Trench 1) to a depth of $1.87 \mathrm{~m} \mathrm{bgl}$ on the south side of the Turker Beck on the line of the W-E transect recorded by Rackham and Clay (2014), and close to the point where the samples dated by these authors were recovered. One representative section was described (Table 2) and a column sample (column $<1>$ ) collected from the cleaned section between $1.20 \mathrm{~m}$ and $1.70 \mathrm{~m}$ below ground surface (49.44 to $48.94 \mathrm{~m}$ OD). In addition, a continuous sequence of $5 \mathrm{~cm}$ thick bulk samples (samples $<1>$ to $<7>$ ) was extracted between 49.39 and $49.04 \mathrm{~m}$ OD. Detailed lithostratigraphic and geochronological investigations were undertaken on the column sample, supplemented by field descriptions of the sediments above and below these levels. In the field, the lithostratigraphic sequence was described using Troels-Smith (1955), with additional descriptions of column $<1>$ in the laboratory. Fragments of twig wood were recovered from column sample $<1>$ to be submitted for radiocarbon assay. The integrated results of these investigations, showing the position of column $\langle 1\rangle$, and the bulk samples within Trench 1 and the position of the material sampled for radiocarbon assay, are shown in Figure 3.

\subsection{Biostratigraphy}

Detailed biostratigraphic investigations were undertaken on sub-samples of material derived from column sample $<1>$ and bulk samples $<1>,<3>,<5>$ and $<7>$ (see Figure 3 ). Pollen samples were extracted following standard procedures: sieving, heavy liquid flotation and acetolysis, with the slides mounted in glycerol jelly (Branch et al., 2005). The pollen record was rather sparse, but five samples contained sufficient concentration and preservation of remains for full analysis; the remaining four samples were assessed only. Pollen grains and spores were identified using the University of Reading pollen type collection and the keys and photographs in Moore et al. (1991) and Reille (1992). The concentration of microscopic charred particles was also recorded. The results of the pollen analysis are shown in Figure 4.

Macrofossil remains (including seeds, fruit bodies, Mollusca and calcareous microfauna/flora), were extracted by dispersal in hot water, and sieving through $1 \mathrm{~mm}, 300$ $\mu \mathrm{m}$ and $125 \mu \mathrm{m}$ mesh sizes. All extracted seeds and fruits were identified using modern comparative material and reference atlases (e.g. Cappers et al., 2006). Sixty nine randomly selected fragments of wood were examined following standard procedures, as described in Hather (2000) (Table 3). Nomenclature follows Stace (2005). Five additional samples of wood were identified for the final phase of radiocarbon dating, of which one was selected for dating. This sample was confirmed as Alnus sp. (alder) with a small central pith present, indicating that it derives from aerial wood rather than root material (see Figure 5). 
Identifications of Mollusca and calcareous microflora/fauna were made with reference to Kerney (1999), Athersuch et al. (1989) and Meisch (2000). The abundance of calcareous microflora/fauna in the samples was assessed on a six-point scale, where $0=$ absent; $1=$ present ( 1 individual); $2=$ rare (2-4); $3=$ common (5-14); $4=$ abundant $(15-49) ; 5=$ dominant $(50+)$. Insect remains were processed by paraffin flotation following Atkinson et al. (1987). In addition, the insect assemblages were combined on a sample-by-sample basis using the Mutual Climatic Range (MCR) approach to determine the palaeoclimate and any climatic variations through the sequence. The methodological approach to the MCR follows that of Elias (1997). The combined results of the macrofossil, wood and calcareous microfossil analyses are displayed in Figure 6; Mollusca are not shown since they were present in relatively low concentrations. The results of the insect analysis are displayed in Table 4.

\subsection{Geochronology}

Dating of these organic sediments was undertaken in four stages, the results displayed in Table 5 and Figure 3. The results have been calibrated using OxCal 4.3 Bronk Ramsey (2009) and the IntCal13 atmospheric curve (Reimer et al., 2013). Following on from the radiocarbon dating undertaken by Rackham \& Clay (2014), two unidentified twig (short-lived) wood samples were submitted to the Scottish Universities Environmental Research Centre (SUERC) Radiocarbon Dating Facility, East Kilbride, Scotland following the standard acidbase-acid pre-treatment and analytical procedures shown in Dunbar et al. (2016). Sample taxa were not determined prior to assay, since the samples were twig wood likely to be less than 5 years old and are therefore not subject to the error associated with long-lived species. The younger of the two SUERC dates (5040-4870 cal a BP; SUERC-54713) was obtained from the base of the peat unit (Unit 10). The earlier SUERC date (14700-14160 cal a BP; SUERC-54714) was obtained from the richly organic silty sand of Unit 8 between $49.12 \mathrm{~m}$ and $49.15 \mathrm{~m}$ OD. Two further samples were then extracted and submitted for dating to the Beta Analytic INC Radiocarbon Dating Laboratory, Florida, USA, again using standard acidbase-acid pre-treatment and analytical procedures. Both samples were identified prior to assay. One sample was of Salix/Populus sp. (willow/poplar) from Unit 8 (BETA-396040) and the other of Alnus sp. (alder) from Unit 7 (BETA-396039). Both samples returned dates generally similar to the earlier of the two SUERC dates, in the range 14000 to $14340 \mathrm{cal}$ a BP. Finally, an additional sample of Alnus sp. (alder) twig wood was submitted for AMS radiocarbon dating to SUERC. The sample was obtained from 49.15 to $49.14 \mathrm{~m}$ OD and returned an age of 14295-14045 cal a BP (SUERC-81422).

In all samples the $\delta 13 \mathrm{C}(\%)$ values are consistent with those expected for terrestrial plant remains (see Boutton, 1991), and there is no evidence for mineral or biogenic carbonate contamination (including the hard-water effect). Howard et al. (2009) suggest some caution when dating macrofossil remains from fluvial sediments, suggesting that macrofossil remains may be slightly younger than the sediments in which they are found due to downward penetration of (for example) Phragmites roots. However, the number and consistency of the dates obtained, all from Units 7 and 8, indicate that they provide a reliable age for the sediments encountered here. In addition, the significance of the dated macrofossils here lies in their early date, and if they are of an order of magnitude younger as suggested by Howard et al. (2009) (generally ca. 300-700 years), these remain within the Lateglacial period.

\section{Results and interpretation}

\subsection{Lithostratigraphy}

At the base of the sediment sequence a silty and sandy gravel (Unit 1) is present that passes up into a silty and clayey gravel (Units 2 and 4 ) with a thin intercalated unit of stoneless silty 
clay (Unit 3). This transition suggests a change to a less energetic discharge regime or a shift away from proximity to an active channel. These gravelly sediments in which visible organic material is very scarce or absent are overlain by fine-grained organic units, possibly representing three fining-upward sequences (Units $4 \& 5$, Units $6 \& 7$, Units $8 \& 9$ ). These fining upward sequences probably represent episodic influx of sand-rich floodwater into a shallow backwater or floodplain pond followed by accumulation of silts and clays settling from slow-moving or standing water. There was detrital wood and herbaceous material throughout this sequence of fine-grained sediments with a marked concentration in the thin sandy unit (Unit 8) between 49.12m and 49.15m OD. In addition, in the two upper pairs of units, Mollusca were also present. These organic remains are likely to include material derived from both local and more distant source areas. The quiet-water deposition represented by the silt and clay of Unit 9 was succeeded by the accumulation of peat (Unit 10 ), reflecting a shift of open water conditions away from the sample location, although the silt content in the peat indicates that the site was still subject to flooding. Overlying the peat are $1.28 \mathrm{~m}$ of silty clay and clay (Units 11-14) in which no visible organic remains were recorded apart from roots penetrating from the present-day ground surface. These sediments are typical of floodplain deposits settling from slow-moving or standing water, and are representative of conditions similar to those of the modern floodplain of the Turker Beck.

\subsection{Biostratigraphy}

\subsubsection{Pollen}

The pollen samples exhibited a similar assemblage throughout the sequence of organic sediments (Units 5-10) and thus the diagram was not sub-divided into local pollen assemblage zones (Figure 4). The pollen indicates an open environment dominated by herbaceous taxa comprising Cyperaceae (70\%) and Poaceae (10\%) with sporadic occurrences of a range of other taxa including: cf Thalictrum, Asteraceae, Cirsium type, Artemisia, Caryophyllaceae, Lactuceae, Rumex acetosa/acetosella, Plantago media/major, Ranunculus type and Galium type (all <1\%). The nearby and/or regional presence of woodland is indicated by consistent values of tree $(<10 \%)$ and shrub $(<4 \%)$ pollen, dominated by Betula $(<10 \%)$ with Salix $(<3 \%)$, Pinus $(<2 \%)$ and Corylus type $(1 \%)$. Aquatic taxa were limited to a few grains of Myriophyllum and Sparganium type towards the base of the sequence, and Potamogeton towards the top. Spore taxa are represented by limited numbers of Filicales (2\%). In general, these taxa are typical of the relatively open, tundralike environments of the Lateglacial period in Britain, whilst the Cyperaceae and aquatic taxa are indicative of a damp floodplain environment. Furthermore, the presence of Myriophyllum provides evidence for minimum July temperatures of $10^{\circ} \mathrm{C}$ (Kolstrup, 1979). Microcharcoal was also recorded suggestive of burning but concentrations were generally low $(<3000$ fragments $\left./ \mathrm{cm}^{3}\right)$, with higher values from the sample at $49.28 \mathrm{~m}$ OD $\left(11,000 \mathrm{fragments} / \mathrm{cm}^{3}\right)$.

\subsubsection{Waterlogged seeds}

In the organic-rich mineral sediments forming Units 6-9, the assemblage of waterlogged seeds is generally dominated by aquatic or herbaceous taxa, all of which are also represented in the pollen record including Potamogeton sp., Scirpus sp., Eleocharis sp., Carex sp., Rumex/Polygonum sp. and Ranunculus repens. This assemblage is typical of a wet or damp environment, perhaps on the margins of a pond or backwater in which pondweed was growing with bulrush, sedges, spikerushes and creeping buttercup on its margins. Dock, sorrel or knotweed are likely to have occupied drier ground nearby. In the silty sand of Unit 8 the assemblage is slightly different with more seeds of Scirpus sp. and other sedges, and fewer seeds of Potamogeton sp., perhaps reflecting in-wash of material from floodwater. In the overlying peat of Unit 10 seed preservation is poor, with only two 
seeds identified, Ranunculus repens and Scirpus sp. No aquatic taxa were found in this part of the sequence.

\subsubsection{Waterlogged wood}

Small branches and twigs of wood were present in all the samples examined both in the mineral sediment of Units 6-9 and in the overlying peat (Unit 10). Only in Unit 8 was there a noticeable decrease in the amount of wood present, possibly reflecting the more energetic depositional environment of this (possibly flood-related) sandy deposit. Of the 69 pieces of wood examined (see Table 3), 59 belonged to a single taxon, Alnus sp. (alder); two pieces were assigned to Salix/Populus sp. (willow/poplar) and the identity of the remaining 8 fragments could not be determined. These twigs and branches appear to represent accumulation of water-borne woody debris from alder woodland, with stands of willow or poplar, present in the catchment of the Turker Beck near to and/or upstream from the sample site. Photographs of thin sections of this and other selected wood specimens identified as alder are shown in Figure 5. All the elements examined had scalariform perforation plates of 10-16+ bars. According to Schweingruber (1990) Alnus glutinosa (black alder), A. cordata (Italian alder), $A$. orientalis (oriental alder) and $A$. incana (grey alder) cannot be differentiated from each other anatomically, and given the early date for the alder remains described here, it cannot be confirmed that the macrofossil remains are those of the species now native to the UK (black alder). A. viridis (green alder) has distinct characteristics that allow differentiation from the macrofossils identified here; aggregate rays were recorded as present in the samples examined which are absent in $A$. viridis indicating that $A$. viridis is almost certainly not present in the Turker Beck samples.

\subsubsection{Mollusca}

Small numbers of Mollusca were recovered from Units 6 and 9. Both units contained limited assemblages of species with numerous juveniles and many individuals were small relative to the recorded size of adults of the species represented. In both units the commonest species were the Succineidae probably including both $S$. putris/Oxyloma pfeifferi and $S$. oblonga/Catinella arenaria. Other species present, Lymnaea trucatula, Gyraulus laevis, Pisidium spp. and Vallonia pulchella all favour marshy habitats or wet grassland. G. laevis is a common species in Lateglacial deposits and $V$. pulchella is often present in large numbers in flood debris on alluvial floodplains.

\subsubsection{Calcareous microfossils (Ostracoda and Charophyta)}

Charophyte oogonia were common in the organic-rich mineral sediment of Units 6-9 and especially so in Unit 6, but infrequent above Unit 9. Ostracods however were common throughout both the mineral-rich units and the overlying peat of Unit 10. Moreover the ostracod assemblage was closely similar in all the samples examined in this sequence. Adult specimens of Candona candida were common and there were numerous juvenile specimens probably of the same species. Cypridopsis vidua was common in the upper part of the sequence (Units 9 and 10) but was absent lower down in Unit 6. Pseudocandona spp. and Potamocypris villosa were less common, and Heterocypris salina was rare. A few specimens of the ostracod Pseudocandona spp. and some charophyte oogonia were present in the silts and clays of Unit 11 overlying the peat. All the ostracod species recovered were represented by both valves and carapaces, together with numerous juveniles indicating that these are in situ assemblages. Together with the charophytes, the assemblages indicate the presence close by of a permanent, still or slow-moving body of clean calcium-rich water. Cypridopsis vidua has been recorded particularly in association with charophytes, so it is noteworthy that in the sample with the highest abundance of charophyte oogonia (Unit 6), this species was absent. This may indicate that the oogonia 
have been transported away from the area of charophyte colonization and that Cypridopsis valves, being less robust, have not survived. This is consistent with the sandy nature and probable flood-related origin of the sediment forming Unit 6.

\subsubsection{Insects}

The insect faunas are recorded in full in Table 4. Species indicative of damp and aquatic environments form the bulk of the assemblages, but species representative of various dryland habitats are also present. In the lower part of the sequence, in the sandy sediments of Unit 6 most of the species are from aquatic environments, including standing or slowrunning water, bogs and muddy riparian margins. An exception is the ground beetle Bembidion obscurellum which now lives on dry, sandy soil in Scandinavia but is not found today in the UK. In the overlying clayey and silty sediment of Unit 9 a greater mixture of dryland and wetland/aquatic environments is represented, possibly reflecting a longer period of accumulation in quiet water. The dryland indicators include open ground inhabitants and species found in woodlands, in leaf litter and under loose deciduous tree bark along woodland margins. There is however abundant evidence of marshy environments, including species inhabiting bogs, damp meadows and marshes and aquatic species variously found in fast-flowing water, ponds, shallow streams and standing water, together with leaf beetles that feed on aquatic plants. In the silty peat of Unit 10 there are again numerous indicators of marshy environments with standing, vegetation-choked water. These remains were probably largely introduced by episodic flooding as indicated by the significant silt content of the peat. The only dryland indicator is the rove beetle Lordithon thorasicus which now lives in woodland bracket fungi.

\section{Discussion}

\subsection{Sedimentary and hydrological history}

The principal interest of the Turker Beck site is a sequence of organic deposits, about $0.5 \mathrm{~m}$ thick, comprising organic sand, silt and clay overlain by a silty peat. These organic deposits are the floodplain deposits of the Turker Beck. The sedimentological evidence and the contained flora and fauna indicate an environment of marsh and swamp with open water forming shallow channels and ponds, and with alder woodland apparently not far away. The similar composition of the insect faunas and the pollen assemblage throughout the sequence, the undisturbed stratification of the sediments and the coherent nature of the ostracod fauna, comprising a natural mixture of adults and juveniles all tend to confirm the integrity of the sequence and the absence of significant re-working or discontinuities. At the sample site the lower part of the sediment sequence (units 4-9) represent deposition in an open water body. The overlying peat (unit 10) marks a transition to semi-terrestrial conditions on this part of the floodplain.

\subsection{Chronology and climate history}

Ten radiocarbon dates have been obtained from the organic sediments, eight in the present investigation and two in the earlier study by Rackham \& Clay (2014) (see Table 5). The samples assayed by Rackham \& Clay came from the base and the top of the organic sequence and yielded dates respectively of 14165-14275 (SUERC-49860) and 1229512385 (SUERC-49861) cal a BP. Four of the dates obtained during the present investigation, from twigs in the sediments underlying the peat, fall in the period 14.7 to $14 \mathrm{k}$ cal a BP. Three of these dates were from samples for which the taxa had been determined prior to assay, respectively Alnus (14340-14120 cal a BP; BETA-396039 and 14295-14045 cal a BP; SUERC-81422) and Salix/Populus (14155-14000 cal a BP; BETA-396040). These dates and the earlier of the two dates obtained by Rackham \& Clay (2014) are within the earlier part of the Lateglacial Interstadial, equivalent to Greenland Interstadial GI-1e and the Bolling 
Interstadial of the Northwest European Lateglacial chronology (see Table 5 and Figure 7). They include the earliest date for organic sediments so far recorded in the Devensian Lateglacial in north east England. The date of 12340 cal a BP (Rackham \& Clay 2014) from the top of the organic sequence is in the earlier part of the Loch Lomond Stadial. The three remaining dates obtained during the present investigation are thought to represent sampling of lateral fragments of a woody root, observed to penetrate almost the whole thickness of the organic sequence in the column sample.

A Bayesian age-depth model was constructed for the part of the sequence in column $<1>$ from which Lateglacial Interstadial dates have been obtained, using a $P$ _Sequence deposition model in OxCal v4.3.2 (Bronk Ramsay, 2017) and the IntCal13 calibration curve (Reimer et al., 2013). The model was run using a variable $\mathrm{k}$ factor, allowing the program to objectively determine the model rigidity in order to account for variations in sedimentation rate, and to obtain optimal age-depth relationships (Bronk Ramsey \& Lee, 2013). Outlier analysis was performed to identify objectively and down-weight any radiocarbon determinations deemed more likely to be erroneous, applying the 'General' outlier model with a prior outlier probability of $5 \%$ to each radiocarbon sample (Bronk Ramsey, 2009). These parameters produced a coherent age model for the sequence (Figure 7), supporting our conclusions that the macrofossils present within the sequence are not substantially reworked from relict outcrops of older sediments. This is supported by the outlier probabilities which are low through the sequence (see Table 5), indicating that the dated macrofossil remains are likely to lie in the correct stratigraphic position.

The two radiocarbon dates at 49.14-49.12m OD (SUERC-54714; 14700-14160 cal a BP and BETA-396040; 14155-14000 cal a BP) however are not statistically consistent, suggesting that at least one of these dates is an outlier. The inconsistency in these calibrated age ranges is attributed to the woody remains used in SUERC-54714 being reworked by current flows or flood events prior to final deposition, and therefore producing an erroneously old age. Woody macrofossils are susceptible to erroneously old age ranges in Lateglacial sedimentary sequences, principally due to reworking prior to final deposition (e.g. Walker et al., 2003; Howard et al., 2009). The age range for SUERC-54714 however is entirely consistent with the strata directly underlying 49.14m OD (BETA-396039), indicating that the degree of fluvial reworking in the Turker Beck sequence is relatively minimal, and that the macrofossils are not derived from substantially older strata. Furthermore, this interpretation is consistent with the fine-grained and organic-rich nature of the Turker Beck deposits, which indicate a low energy and stable depositional environment, with limited potential for the substantial erosion and transportation of coarse-grained deposits.

Alongside these dates, the Mutual Climatic Range (MCR) analysis of the associated insect faunas indicates that throughout the deposition of the organic sediments, the MCR estimates centre around the modern values of the study region, with Tmax and Tmin values of 13 to $19^{\circ} \mathrm{C}$ and -11 to $4^{\circ} \mathrm{C}$ respectively. The presence of Myriophyllum pollen and Eleocharis macrofossils provides further evidence for minimum July temperatures of $10^{\circ} \mathrm{C}$ (Kolstrup, 1979). Such values are not incompatible with the temperatures indicated in the GRIP $\delta 180$ record for several hundred years during the early part of the Lateglacial Interstadial. Furthermore, the MCR temperature ranges at Turker Beck are comparable to other Interstadial records in NE England (e.g. Walker et al., 1993; Lincoln et al., 2017) and elsewhere in the British Isles (e.g. Coope and Lemdahl, 1995; Walker et al., 2003; Lang et al., 2010).

\subsection{Vegetation history}


There are limited palaeobotanical data for the Lateglacial period in the North Yorkshire lowlands (Innes et al., 2009), and the results from the present site contribute to our understanding of the environment in northern Britain during the earlier part of the Greenland Interstadial. The combined results of the palaeobotanical analyses (pollen, seeds and wood) presented here indicate a relatively consistent vegetation history throughout the deposition of the sequence described above. The pollen record indicates an open environment dominated by herbaceous taxa on both the wetland and dryland surfaces, with stands of birch and willow woodland. Whilst no alder pollen (with the exception of one badly corroded grain) or seeds are recorded, the waterlogged wood assemblage is indicative of alder woodland on the wetland surface with some stands of willow or poplar (the pollen record supporting the presence of the former). The waterlogged seeds indicate wet conditions, particularly below $49.20 \mathrm{~m}$ OD, where an environment on the margin-of a water body is suggested by the presence of aquatic taxa and sedges. Above $49.20 \mathrm{~m}$ OD seed concentrations are low, but the reduction in aquatic taxa may reflect the transition to more terrestrial conditions that occurs here leading to peat formation.

Palaeoenvironmental investigations in the Vale of Mowbray at Snape Mires ca. 15km to the southwest (Innes et al., 2009; Figure 1) record a sequence of similar age to that recorded at Turker Beck, with a radiocarbon date of 14600-14050 cal a BP. Here the pollen assemblage is similar to the assemblage at Turker Beck and is interpreted as representing the pioneer plant communities of the Lateglacial Interstadial (Greenland Interstadial Gl-1e), with very open grass/sedge tundra vegetation persisting for the first few centuries of the Interstadial before an expansion of birch and juniper after ca. 14.5k cal a BP (Innes et al., 2009). The climate oscillations of the Lateglacial period are also recorded in a pollen record from lake deposits near Tadcaster (Bartley, 1962). Although undated, the pollen assemblages interpreted there as Lateglacial in age show similarities to those recorded at Turker Beck, with the apparent dominance of sedges, grasses and birch, with pine, hazel and willow also present. Similar assemblages for the Lateglacial period are recorded at Star Carr (Day, 1996), where grasses and sedges dominate with scattered birch and willow being replaced by juniper later in the sequence.

\subsection{The British and wider European Lateglacial history of Alnus (alder)}

In the literature on the Lateglacial history of alder in Europe, relatively little attention has been given to which species might be represented by surviving pollen and macrofossils. The climatic and edaphic requirements of the two Alder species differ, with the range of $A$. glutinosa being narrower with regards to its minimum summer temperature requirement. $A$. incana is more tolerant with respect to lower summer temperatures and its hydrological demands, this species being able to tolerate drought whilst $A$. glutinosa is more tolerant of flooding (Tallantire, 1974). Godwin (1975, p. 260) recognized the possibility that evidence of Alnus incana might be encountered in Pleistocene deposits in Britain but in fact this species has been recorded only once in Britain, by Heyworth (1985) in the form of pollen in a Lateglacial deposit in west Wales. More recently macrofossil remains of $A$. incana have been recorded in the Netherlands (Bos et al., 2005) in an Early Holocene (Preboreal) deposit, but otherwise in Europe the distribution of $A$. incana is either eastern or montane, including the Alps and Scandinavia (Giesecke \& Brewer, 2018). As noted above it is not possible to identify to species level the wood samples recovered at Turker Beck. However, given the almost complete absence from the British record, before or since the Lateglacial of alder species other than A. glutinosa (Godwin, 1975, p.259), a tentative attribution of the Turker Beck remains to this species seems reasonable, and consistent with the Postglacial history of alder in Britain. 
The spread of tree species in Europe following the LGM has attracted conflicting interpretations both in the British Isles and more widely in Europe, and the history of alder is no exception. Huntley \& Birks (1983) suggested that the main LGM refugia for alder were in the eastern Alps, Carpathians and the Ukrainian Lowlands, with other refugia in Corsica, western France, northern Spain and northwestern Russia. However, evidence for more northerly European refugia has been presented from LGM and Lateglacial sites in Scandinavia (Kullman, 2002)and central and eastern Europe (Willis \& van Andel, 2004). Binney et al. (2009), investigating the distribution of woody taxa in the late Quaternary, have drawn attention to macrofossil records of Alnus spp. in refugia in northern Eurasia during various stages of the Lateglacial period, including a record in Russia dated to $19.4 \mathrm{k}$ cal a $\mathrm{BP}$, and evidence of $A$. fructicosa (Siberian alder) and $A$. glutinosa in Belarus during the period 13-11k cal a BP. Douda et al. (2014), in a systematic review of both pollen and plant macrofossil records, also provide evidence for the expansion of alder from northern cryptic refugia in Europe. The significance of some of this evidence and in some cases its reliability have been challenged, notably by Birks et al. $(2005,2006,2012)$ and Tzedakis (2013), but in a more recent paper Birks (2019) has acknowledged that trees may have survived the LGM in Europe in 'scattered, even locally frequent microrefugia in central, eastern and possibly western and northeastern Europe.'

In the British Isles a similar lack of consensus is apparent and the record and interpretation of Lateglacial alder remains is uneven. Bennett \& Birks (1990, p.127) argued that "The available record suggests that alder was present in the British Isles early in the postglacial, was probably present as early as $10 \mathrm{k}$ a BP (ca. 11.5k cal a BP), and conceivably present even earlier", suggesting that "alder may have been present throughout the last cold stage" (Devensian Glaciation MIS 2-4). At sites in North Yorkshire near to Turker Beck, a continuous pollen record indicative of alder woodland is generally present from about $8 \mathrm{k}$ a BP, e.g. Newby Wiske (Bridgland et al., 2011, Fig. 37, p.115) and this seems to be the case elsewhere in Britain: "... a major expansion of existing Alnus does seem to have taken place in the British Isles in the millennium from ca. 7.5k a BP" (Chambers \& Elliot 1989, p.541). Tallantire (1992) considers $A$. glutinosa to have become established in the southeast of England shortly before $8000 \mathrm{BP}$, perhaps as early as $8300 \mathrm{BP}$, with a delayed expansion northwards and westwards. These later dates were considered by Tallantire (1992) to provide evidence for an expansion of alder from more continental refugia, specifically Western Germany or Holland. However, there are indications that alder was present in the British Isles before this expansion took place, and the review by Douda et al. (2014) of European pollen and plant macrofossil records provides evidence for its expansion from more northerly cryptic refugia, with possible LGM and Lateglacial refugia in south-western and south-eastern England, though they considered the low concentration of alder pollen here more likely to reflect wind transport of pollen from more distant sites.

Evidence for the presence of alder in the LGM or the Lateglacial has been reported from various parts of the British Isles, and a useful summary of the pollen records for this period in Britain is provided by Brewer et al. (2017). Kelly et al. (2010) recorded alder pollen in a deposit of LGM date from a site on Bodmin Moor in the south-west of England, noting the fresh appearance of the pollen but recognizing the possibility of reworking or a windblown origin. Walker (1982) recorded sporadic occurrences of alder pollen at Traeth Mawr (South Wales) during the middle part of the Lateglacial Interstadial (ca. 13500-12500 cal a BP) and as noted above, pollen of $A$. incana was recorded by Heyworth (1985) in a Lateglacial sequence in west Wales. Alder pollen is recorded in low concentrations in several Lateglacial Interstadial sequences from Ireland (e.g. Barnosky, 1988; Browne, 1986; Craig, 1978; Hawthorne, 2015; McKeever, 1984) and in North Wales (Lowe \& Lowe, 1989). The 
findings of Bush \& Hall (1987) also support the view that alder was present in Britain at least as far back as the Lateglacial. They reported alder macrofossils from Late Devensian valley mire deposits at Willow Garth (NGR: TA 126 676) in North Humberside, although the Lateglacial part of their sequence remains undated and Tallantire (1992) raises doubts as to the pre-Holocene presence of alder at this site. There are indications at the Star Carr site that alder was present in the Vale of Pickering during the Lateglacial, although this is in the form of sporadic occurrences of its pollen in this part of the sequence (Day, 1996). More recently Candy et al. (2016) recorded alder pollen in a lacustrine sequence at Tirinie in the Scottish Highlands, broadly contemporaneous with or post-dating the Penifiler tephra (13873-14005 cal a BP; Bronk Ramsey et al., 2015). On the other hand, Jones et al. (2002) record no alder pollen at Hawes Water (Lancashire) during the Lateglacial Interstadial and Lowe \& Lowe (1989) consider the presence of alder and other tree pollen, together with high percentages of pine and pre-Quaternary palynomorphs at their Llyn Gwernan site in North Wales, to be derived from either long-distance transport and/or recycling of older sediments. While this evidence for the presence of alder in Britain in the LGM and Lateglacial is patchy, the pollen of $A$. incana has been detected at only one site (Heyworth, 1985), whereas pollen attributable to $A$. glutinosa is recorded elsewhere from Devon (Kelly et al., 2010) to the Scottish Highlands (Candy et al., 2016). This pattern adds weight to the view expressed above that the attribution of the Turker Beck remains to this species is not unreasonable.

A factor complicating an understanding of the Lateglacial history of alder is uncertainty regarding the significance of alder pollen in the pollen record, or more particularly its absence from the record where there is reason to believe that alder trees were present. This latter situation has been reported from sites in Scandinavia (Moe, 1998; Kullman, 1998; 2008) and from central and eastern Europe (Willis \& van Andel, 2004; Birks \& Willis, 2008; Douda et al., 2014), and Hicks (2006) discusses the issue of the absence of tree pollen, in a location where that species is expected to be growing, more generally. At Turker Beck the evidence for the presence of alder trees is in the form of twigs and small branches of alder wood. No catkins or fruit were observed and no pollen, with the exception of one badly corroded grain. This might indicate that only young trees were present here, in a situation where alder was expanding its range as a response to an ameliorating climate, as suggested by Hicks (2006). Moe (1998) showed that pollen production for Alnus incana (grey alder) was almost zero at its ecotonal limit, with the temperature of the preceding summer, length of the growing season and soil factors suggested as limiting factors in pollen production. A number of investigations of tree species at their range limits in Scandinavia show that pollen production can be severely impacted by summer temperature (e.g. Barnekow et al., 2007; Mazier et al., 2012), whilst Paus \& Haugland (2017) showed a marked discrepancy between the macrofossil and pollen records of tree species and highlighted the influence of temperature on pollen production. McVean (1953) has shown that alder can take up to thirty years to reach reproductive maturity depending on ecotype and environmental conditions. There is also evidence that where alder is only locally present its pollen record can be problematic; Parsons et al. (1980), Prentice (1983), and Prentice et al. (1987) have shown that the frequency of alder pollen in lake sediments can be a poor indicator of the abundance of alder trees in the surrounding landscape. Chambers \& Price (1985) and Chambers \& Elliott (1989) also argued that alder could be locally present within a region, but its pollen not recorded at most sites there. Hicks (2006) considers the complete absence of pollen in a location in which that tree species is growing to be a very rare occurrence; he found that this situation was only achieved where trees are extremely few and widely scattered in the landscape - a conceivable situation for alder during the Lateglacial Interstadial at the present site, where it was growing (at least initially) at the limits of its range (e.g. von Stedingk, 2008). 
The absence of alder pollen at Turker Beck, in a sequence in which its macrofossil remains are relatively abundant, indicates that in Britain as elsewhere in Europe the absence of alder pollen does not reliably indicate an absence of alder trees, although it should be noted here that the pollen record from the present site was rather sparse. The early dates for these Turker Beck macrofossils, in the Lateglacial Interstadial (GRIP GI-1e), contributes to the growing body of evidence for scattered northern refugia for this species during the Last Glacial Maximum, and may indicate that such refugia existed in Britain at this time. Stewart \& Lister (2001) suggest that cryptic refugia would have been in areas of sheltered floodplain topography, providing a suitable microclimate for small stands of alder to survive. Presumably these microrefugia would have been located somewhere to the south of the ice front and south of Turker Beck.

\section{Conclusions}

- Wood macrofossils of alder from alluvial deposits of the Turker Beck in north-east England have been dated to the early part of the Lateglacial Interstadial (14.7-14.0 cal a BP), equivalent to Greenland Interstadial GI-1e and the Bølling Interstadial of the north-west European Lateglacial chronology.

- These are the earliest dates recorded for the presence of alder in the Lateglacial in the British Isles and show that alder trees were growing in north-east England at this time. This evidence for the rapid recovery of tree species in Britain following the LGM lends support to the view, based on evidence in northern, central and eastern Europe, that following deglaciation the spread of trees (and other species) may have involved expansion of small populations from cryptic refugia relatively close to the ice margin, possibly including localities in Britain, rather than exclusively by northward migration from larger refugia in southern Europe as originally argued by Huntley \& Birks (1983) and Bennett et al. (1991). Such evidence provides an insight into the resilience of wetland forest habitats in the context of global climate change.

- The lack of alder pollen in the sediment from which the alder wood was recovered at Turker Beck is also consistent with findings elsewhere in Europe that an absence of alder pollen does not reliably indicate an absence of alder trees.

- The biological remains associated with the alder macrofossils at Turker Beck provide a new palaeoenvironmental record for the early part of the Lateglacial Interstadial, a period for which few palaeoecological records are otherwise available in Britain. The record indicates an open environment dominated by herbaceous taxa on both wetland and dryland surfaces, with scattered stands of birch, willow and alder woodland. The insect assemblage recovered from the sequence supports Mutual Climatic Range (MCR) estimates that centre on modern values for the region (Tmax 13 to $19^{\circ} \mathrm{C}$; $\operatorname{Tmin}-11$ to $4^{\circ} \mathrm{C}$ ), and are comparable to previous summer temperature estimates for this period in Britain.

\section{Acknowledgements}

We are grateful to Stephen Kemp and the Environment Agency for commissioning Quaternary Scientific (QUEST), University of Reading to carry out the analytical work that forms the basis of this publication, and for funding earlier stages of the work. We thank Allen Archaeology Limited for making available the results of their previous investigations at the site. We are extremely grateful to Professor Nick Branch and anonymous reviewers, who provided very helpful comments on previous drafts of this manuscript. 


\section{References}

Athersuch J, Horne DJ, Whittaker JE. 1989. Marine and Brackish Water Ostracods. Synopses of the British Fauna (New Series) No.43. Brill, Leiden.

Atkinson TC, Briffa KR, Coope GR. 1987. Seasonal temperatures in Britain during the past 22,000 years, reconstructed using beetle remains. Nature 325: 587-592.

Bartley DD. 1962. The stratigraphy and pollen analysis of lake deposits near Tadcaster, Yorkshire. New Phytologist 61: 277-287.

Barnekow L, Loader NJ, Hicks $S$ et al. 2007. Strong correlation between summer temperature and pollen accumulation rates for Pinus sy/vestris, Picea abies and Betula spp. in a high-resolution record from northern Sweden. Journal of Quaternary Science 22(7): 653-658.

Barnosky CW. 1988. A late-glacial and post-glacial pollen record from the Dingle Peninsula, County Kerry. Proceedings of the Royal Irish Academy 88B: 23-37.

Bateman MD, Murton JB, Chase B et al. 2008. The Late Devensian pro-glacial Lake Humber: new evidence from littoral deposits at Ferrybridge, Yorkshire, England. Boreas, 37: 195-210.

Bellamy DJ, Bradshaw ME, Millington MR et al. 1966. Two Quaternary deposits in the Tees basin. New Phytologist 65: 429-442.

Bennett KD, Birks HJB. 1990. Postglacial history of alder (Alnus glutinosa (L.) Gaertn.) in the British Isles. Journal of Quaternary Science 5: 123-133.

Binney HA, Willis KJ, Edwards ME et al. 2009. The distribution of late-Quaternary woody taxa in northern Eurasia: evidence from a new macrofossil database. Quaternary Science Reviews 28 (23-24): 2445-2464.

Birks HJB, Willis KJ. 2008. Alpines, trees, and refugia in Europe. Plant Ecology \& Diversity 1(2): 147-160.

Birks HH, Larsen E, Birks HJB. 2005 Did tree-Betula, Pinus and Picea survive the last glaciation along the west coast of Norway? A review of the evidence, in light of Kullman (2002). Journal of Biogeography 32: 1461-1471.

Birks $\mathrm{HH}$, Larsen E, Birks HJB. 2006. On the presence of late-glacial trees in western Norway and the Scandes: a further comment. Journal of Biogeography 33: 376-378.

Birks HH, Giesecke T, Hewitt GM et al. 2012. Comment on "Glacial Survival of Boreal Trees in Northern Scandinavia". Science 338: 742.

Birks HJB. 2019. Contributions of Quaternary botany to modern ecology and biogeography. Plant Ecology \& Diversity 12(3-4): 189-385.

Blackburn K. 1952. The dating of a deposit containing an elk skeleton found at Neasham, near Darlington, County Durham. New Phytologist 51: 364-377. 
Blackham A, Davies C, Flenley J. 1981. Evidence for late Devensian landslipping and late Flandrian forest regeneration at Gormire Lake, North Yorkshire. In: Neale, J., Flenley, J. (Eds.), The Quaternary in Britain. Pergamon Press, London, pp. 184-194.

Boutton TW. 1991. Stable carbon isotope ratios of natural materials. II. Atmospheric, terrestrial, marine and freshwater environments. In: Coleman, D.C., Fry, B. (Eds.), Carbon Isotope Techniques. Academic Press, San Diego \& London, pp. 173-186.

Bos JAA, Huisman DJ, Kiden P et al. 2005 Early Holocene environmental change in the Kreekrak area (Zeeland, SW-Netherlands): A multi-proxy analysis. Palaeogeography, Palaeoclimatology, Palaeoecology 227: 259- 289.

Branch NP, Canti MG, Clark P et al. 2005. Environmental Archaeology: Theoretical and Practical Approaches. Edward Arnold, London.

Bray PJ, Blockley SPE, Coope GR et al. 2006. Refining Mutual Climatic Range (MCR) quantitative estimates of palaeotemperature using Ubiquity Analysis. Quaternary Science Reviews, 25(15-16): 1865-1876.

Brewer S, Giesecke T, Davis BAS et al. 2017. Late-glacial and Holocene European pollen data. Journal of Maps 13(2): 921-928.

Bridgland D, Innes J, Long A et al. 2011. Late Quaternary landscape evolution of the SwaleUre Washlands, North Yorkshire. Oxbow Books, Oxford.

Bronk Ramsey C. 2008. Deposition models for chronological records. Quaternary Science Reviews 27(1-2), 42-60.

Bronk Ramsey C. 2009. Bayesian analysis of radiocarbon dates. Radiocarbon 51(1), 337360.

Bronk Ramsey C. 2017. Methods for Summarizing Radiocarbon Datasets. Radiocarbon 59(2), 1809-1833.

Bronk Ramsey C, Lee S. 2013. Recent and Planned Developments of the Program OxCal. Radiocarbon 55(2-3), 720-730.

Bronk Ramsey C, Albert PG, Blockley SPE et al. 2015. Improved age estimates for key Late Quaternary European tephra horizons in the RESET lattice. Quaternary Science Reviews 118: $18-32$.

Brooks SJ, Birks HJB. 2000. Chironomid-inferred Late-glacial air temperatures at Whitrig Bog, Southeast Scotland. Journal of Quaternary Science 15(8): 759-764.

Brooks SJ, Matthews IP, Birks HH et al. 2012. High resolution Lateglacial and earlyHolocene summer air temperature records from Scotland inferred from chironomid assemblages. Quaternary Science Reviews 41: 67-82.

Browne PR. 1986. Pollen stratigraphy in the Nephin Begs Co, Mayo. Doctoral dissertation. University of Dublin, Trinity College, Dublin, Ireland. 
Bush MB, Hall AR. 1987. Flandrian Alnus: expansion or immigration? Journal of Biogeography, 14: 479-481.

Candy I, Abrook A, Elliot F et al. 2016. Oxygen isotopic evidence for high-magnitude, abrupt climatic events during the Lateglacial Interstadial in north-west Europe: analysis of a lacustrine sequence from the site of Tirinie, Scottish Highlands. Journal of Quaternary Science 31(6): 607-621.

Cappers RTJ, Bekker RM, Jans JEA. 2006. Digital Seed Atlas of the Netherlands. Groningen Archaeological Series 4, Barkhuis, Netherlands.

Clark CD, Hughes ALC, Greenwood SL et al. 2010. Pattern and timing of retreat of the last British-Irish Ice Sheet. Quaternary Science Reviews 44: 112-146.

Chambers FM, Elliott L. 1989. Spread and expansion of Alnus Mill. In the British Isles: timing, agencies and possible vectors. Journal of Biogeography, 16: 541-550.

Chambers FM, Price SM. 1985. Palaeoecology of Alnus (alder): early post-glacial rise in a valley mire, northwest Wales. New Phytologist 101: 333-344.

Coope GR. 1987. Fossil beetle assemblages as evidence for sudden and intense climatic change in the British Isles during the last 45,000 years. In (W.H. Berger \& L.D. Labeyrie, eds.) Abrupt Climate Change, pp. 147-150. Reidel, Dordrecht, The Netherlands.

Coope GR, Lemdahl G. 1995. Regional differences in the Lateglacial climate of northern Europe based on coleopteran analysis. Journal of Quaternary Science 10: 391-395.

Coope GR. Lemdahl G, Lowe JJ et al. 1998. Temperature gradients in northern Europe during the last glacial-Holocene transition (14-9 ${ }^{14} \mathrm{C}$ kyr BP) interpreted from coleopteran assemblages. Journal of Quaternary Science 13: 419-433.

Craig AJ. 1978. Pollen percentage and influx analysis in southeast Ireland: a contribution to the ecological history of the Late-glacial period. Journal of Ecology 66: 297-324.

Cundill P, Whittington G. 1983. Anomalous arboreal pollen assemblages in Late Devensian and Early Flandrian deposits at Creich Castle, Fife, Scotland. Boreas 12: 297-311.

Day P. 1996. Devensian late-glacial and early Flandrian environmental history of the Vale of Pickering. Journal of Quaternary Science 11: 9-24.

Douda J, Doudová J, Drašnarová A et al. 2014. Migration Patterns of Subgenus Alnus in Europe since the Last Glacial Maximum: A Systematic Review. PLoS ONE 9(2): e88709.

Dunbar E, Cook, G, Naysmith, P et al. 2016. AMS 14C Dating at the Scottish Universities Environmental Research Centre (SUERC) Radiocarbon Dating Laboratory. Radiocarbon, 58(1), 9-23.

Elias SA. 1997. The mutual climatic range method of palaeoclimate reconstruction based on insect fossils: New applications and interhemispheric comparisons. Quaternary Science Reviews 16(10): 1217-1225. 
Elias SA. 2007. Beetle records. In (S.A. Elias, ed) Encyclopedia of Quaternary Science, 153163. Elsevier.

Environment Agency 2013. Northallerton Ground Investigation Factual Report 2013. Unpublished Report - Job No. AO78229-1.

Froyd C. 2005. Fossil Stomata Reveal Early Pine Presence in Scotland: Implications for Postglacial Colonization Analyses. Ecology 86(3): 579-586.

Gearey BR. (2008) Lateglacial vegetation change in East Yorkshire: a radiocarbon dated pollen sequence from Routh Quarry, Beverley. Proceedings of the Yorkshire Geological Society 57: 113-122.

Giles JRA. 1992. Late Devensian and early Flandrian environments at Dishforth Bog, north Yorkshire. Proceedings of the Yorkshire Geological Society 49: 1-10.

Giesecke T, Brewer S. 2018. Notes on the postglacial spread of abundant European tree taxa. Vegetation History and Archaeobotany 27: 337-349.

Godwin H. 1975. The history of the British flora: a factual basis for phytogeography. Cambridge: Cambridge University Press.

Hather JG. 2000. The Identification of the Northern European Woods. A guide for archaeologists and conservators. Archetype: London.

Hawthorne D. 2015. Quantifying fire regimes and their impact on the Irish landscape. Doctoral dissertation. Trinity College Dublin, Dublin, Ireland.

Heyworth A, Kidson C, Wilks P. 1985. Late-Glacial and Holocene Sediments at Clarach Bay, Near Aberystwyth. Journal of Ecology 73(2): 459-480.

Hicks S. 2006. When no pollen does not mean no trees. Vegetation History and Archaeobotany 15: 253-261.

Huntley B, Birks HJB. 1983. An atlas of past and present pollen maps for Europe: 0-13000 years ago. Cambridge: Cambridge University Press.

Innes JB, Rutherford MM, O'Brien CE et al. 2009. Late Devensian environments in the Vale of Mowbray, North Yorkshire, UK: evidence from palynology. Proceedings of the Geologists' Association 120: 199-208.

Jones RL. 1977a. Late Quaternary vegetational history of the North York Moors. V. The Cleveland Dales. Journal of Biogeography 4: 353-362.

Jones RL. 1977b. Late Devensian deposits from Kildale, north-east Yorkshire. Proceedings of the Yorkshire Geological Society 41: 185-188.

Jones RT, Marshall JD, Crowley SF et al. 2002. A high resolution, multiproxy Late-glacial record of climate change and intrasystem responses in northwest England. Journal of Quaternary Science 17: 329-340. 
Keen DH, Jones RL, Robinson JE. 1984. A Late Devensian and early Flandrian fauna and flora from Kildale, north-east Yorkshire. Proceedings of the Yorkshire Geological Society 44: 385-397.

Kelly A, Charman DJ, Newnham RM. 2010. A Last Glacial Maximum pollen record from Bodmin Moor showing a possible cryptic northern refugium in southwest England. Journal of Quaternary Science 25(3): 296-308.

Kerney M. 1999. Atlas of the Land and Freshwater Molluscs of Britain and Ireland. Colchester: Harley Books.

King RA, Ferris C. 1998. Chloroplast DNA phylogeography of Alnus glutinosa (L.) Gaertn. Molecular Ecology 7: 1151-1161.

Kolstrup E. 1979. Herbs as July Temperature Indicators for Parts of the Pleniglacial and Late-Glacial in the Netherlands. Geologie En Mijnbouw 59(3): 377-380.

Kullman L. 1998. Non-analogous tree flora in the Scandes Mountains, Sweden, during the early Holocene - macrofossil evidence of rapid geographic spread and response to palaeoclimate. Boreas 27: 153-161.

Kullman L. 2002. Boreal tree taxa in the central Scandes during the Late-Glacial: implications for Late-Quaternary forest history. Journal of Biogeography 29: 1117-1124.

Lang B, Brooks SJ, Bedford A et al. 2010. Regional consistency in Lateglacial chironomidinferred temperatures from five sites in north-west England. Quaternary Science Reviews 29: $1528-1538$.

Lillie M, Gearey B. 1999. Further lithostratigraphical and biostratigraphical investigations at Pepper Arden Bottoms, Hambleton District, North Yorkshire. Centre for Wetland Archaeology, University of Hull. Unpub. manuscript. 18pp.

Lincoln PC, Matthews IP, Palmer A et al. 2017. Palaeoenvironmental reconstructions from the Southern Extension of Wykeham Quarry. In: Lincoln PC, Eddey LJ, Matthews IP et al. (eds.). 2017. The Quaternary of the Vale of Pickering: Field Guide. Quaternary Research Association, London.

Lowe JJ, Lowe S. 1989. Interpretation of the pollen stratigraphy of late Devensian lateglacial and early Flandrian sediments of Lhym Gwenan near Cader Idris, north Wales. New Phytologist 113: 391-408.

Matthews IP, Birks HH, Bourne AJ et al. 2011. New age estimates and climatostratigraphic correlations for the Borrobol and Penifiler Tephras: evidence from Abernethy Forest, Scotland. Journal of Quaternary Science 26(3): 247-252.

Mayle FE, Lowe JJ, Sheldrick C. 1997. The Late Devensian Lateglacial palaeoenvironmental record from Whitrig Bog, SE Scotland. 1. Lithostratigraphy and palaeobotany. Boreas 26: 279-295. 
Mayle FE, Bell M, Birks HH et al. 1999. Climate variations in Britain during the last glacialHolocene transition (15.0-11.5 cal ka BP): comparison with the GRIP ice-core record. Journal of the Geological Society, London 156: 411-423.

Mazier F, Nielsen AB, Broström A et al. 2012. Signals of tree volume and temperature in a high-resolution record of pollen accumulation rates in northern Finland. Journal of Quaternary Science 27(6): 564-574.

McKeever MH. 1984. Comparative palynological studies of two lake sites in western Ireland and northwestern Spain. Thesis. Trinity College, Dublin, Ireland.

McVean DN. 1953. Alnus Glutinosa (L.) Gaertn. Journal of Ecology 41(2): 447-466.

Meisch C. 2000. Freshwater Ostracoda of Western and Central Europe. Spektrum Akademischer Verlag. Heidelberg.

Moe D. 1998. Pollen production of Alnus incana at its south Norwegian altitudinal ecotone. Grana 37: 35-39.

Moore PD, Webb JA, Collinson ME. 1991. Pollen Analysis (2nd Ed.). Blackwell: Oxford.

Öberg L, Kullman L. 2011. Ancient Subalpine Clonal Spruces (Picea abies): Sources of Postglacial Vegetation History in the Swedish Scandes. Arctic 64: 183-196.

Parsons RW, Prentice IC, Saarnisto, M. 1980. Statistical studies on pollen representation in Finnish lake sediments in relation to forest inventory data. Annales Botanici Fennici 17: 379393.

Prentice IC. 1983. Pollen mapping of regional vegetation patterns in south and central Sweden. Journal of Biogeography 10: 441-454.

Prentice IC, Berglund BE, Olsson T. 1987. Quantitative forest-composition sensing characteristics of pollen samples from Swedish lakes. Boreas 16: 43-54.

Rackham J, Clay C. 2014. Palaeoenvironmental assessment report - Turker Beck, Bullamoor Road, Northallerton, North Yorkshire. Unpublished Allen Archaeology Report (AAL 2014007)

Rasmussen SO, Bigler M, Blockley SP et al. 2014. A stratigraphic framework for abrupt climatic changes during the Last Glacial period based on three synchronized Greenland icecore records: refining and extending the INTIMATE event stratigraphy. Quaternary Science Reviews 106: 14-28.

Reille M. 1992. Pollen et Spores d'Europe et d'Afrique du Nord. Marseille: Laboratoire de Botanique Historique et Palynologie.

Reimer PJ, Bard E, Bayliss A et al. 2013. IntCal13 and Marine13 radiocarbon age calibration curves 0-50,000 years cal BP. Radiocarbon 55(4):1869-1887.

Schweingruber FH. 1990. Anatomie europäischer Holzer - Anatomy of European woods. Birmensdorf: Haupt. Swiss Federal Institute for Forest, Snow and Landscape Research. 
Stace C. (2005) New Flora of the British Isles (3rd ed.). Cambridge University Press: Cambridge.

Stewart JR, Lister AM. 2001. Cryptic northern refugia and the origins of the modern biota. TRENDS in Ecology \& Evolution 16: 608-613.

Tallantire PA. 1974. The palaeohistory of the grey alder (Alnus incana (L.) Moench.) and black alder (A. glutinosa (L.) Gaertn.) in Fennoscandia. New Phytologist 73: 529-546.

Tallantire PA. 1992. The alder [Alnus glutinosa (L.) Gaertn.] problem in the British Isles: a third approach to its palaeohistory. New Phytologist 122: 717-731.

Tzedakis PC, Emerson BC, Hewitt GM. 2013. Cryptic or mystic? Glacial tree refugia in northern Europe. Trends in Ecology \& Evolution 28(12): 696-704.

Tröels-Smith J. 1955. Karakterisering af løse jordater (Characterisation of unconsolidated sediments), Danm. Geol. Unders., Ser IV 3, 73.

Vandenberghe X, Renssen H, Isarin RFB. 2001. The last glaciation: climate modelling and data analysis. Global and Planetary Change 30: 1-165.

Von Stedingk H, Fyfe RM, Allard A. 2008 Pollen productivity estimates from the foresttundra ecotone in west-central Sweden: implications for vegetation reconstruction at the limits of the boreal forest. The Holocene 18(2): 323-332.

Walker MJC. 1982. The Late-Glacial and Early Flandrian Deposits at Traeth Mawr, Brecon Beacons, South Wales. New Phytologist 90: 177-194.

Walker MJC, Coope GR, Lowe JJ. 1993. The Devensian (Weichselian) late-glacial palaeoenvironmental record from Gransmoor, East Yorkshire, England. Quaternary Science Reviews 12: 659-680.

Walker MJC, Bohncke SJP, Coope GR et al. 1994. The Devensian/Weichselian Late-glacial in northwest Europe (Ireland, Britain, north Belgium, The Netherlands, northwest Germany). Journal of Quaternary Science 9: 109-118.

Walker MJC, Coope GR, Sheldrick C et al. 2003. Devensian late-glacial environmental changes in Britain: a multi-proxy environmental record from Llanilid, South Wales, UK. Quaternary Science Reviews 22: 475-520.

Willis K, van Andel TH. 2004. Trees or no trees? The environments ofcentral and eastern Europe during the Last Glaciation. Quaternary Science Reviews 23: 2369-2387.

Wohlfarth B, Muschitiello F, Greenwood SL et al. 2017. Hässeldala - a key site for Last Termination climate events in northern Europe. Boreas 46: 143-161. 
Table 1: Selected palaeoenvironmental records for the Lateglacial period in Britain.

\begin{tabular}{|c|c|c|c|c|c|c|c|}
\hline Site & Region & Easting & Northing & Reference & Sequence & $\begin{array}{l}\text { Earliest } \\
\text { date (cal a } \\
\text { BP) }\end{array}$ & $\begin{array}{l}\text { Latest date } \\
\text { (cal a BP) }\end{array}$ \\
\hline Gransmoor Quarry & East Yorkshire & 511300 & 459700 & Walker et al., 1993 & $\begin{array}{l}\text { Lateglacial Interstadial- } \\
\text { Loch Lomond Stadial }\end{array}$ & \multicolumn{2}{|c|}{$\begin{array}{l}\text { Dating unreliable (see } \\
\text { Walker et al., 1993) }\end{array}$} \\
\hline Routh Quarry & East Yorkshire & 509476 & 443661 & Gearey, 2008 & $\begin{array}{l}\text { Lateglacial Interstadial- } \\
\text { early Holocene }\end{array}$ & $\begin{array}{l}13280- \\
12980\end{array}$ & $8540-8210$ \\
\hline Snape Mires & North Yorkshire & 427450 & 484100 & Innes et al., 2009 & $\begin{array}{l}\text { Lateglacial Interstadial- } \\
\text { early Holocene }\end{array}$ & $\begin{array}{l}14600- \\
14050\end{array}$ & $\begin{array}{l}11130- \\
10720\end{array}$ \\
\hline Nosterfield & North Yorkshire & 428450 & 480800 & Innes et al., 2009 & $\begin{array}{l}\text { Loch Lomond Stadial-early } \\
\text { Holocene }\end{array}$ & $\begin{array}{l}12940- \\
12830\end{array}$ & $\begin{array}{l}11710- \\
11260\end{array}$ \\
\hline Vale of Pickering & North Yorkshire & 502800 & 481000 & Day, 1996 & $\begin{array}{l}\text { Lateglacial Interstadial- } \\
\text { early Holocene }\end{array}$ & $8600-8220$ & $7565-7275$ \\
\hline Tadcaster & North Yorkshire & 450516 & 443251 & Bartley, 1962 & $\begin{array}{l}\text { Lateglacial Interstadial- } \\
\text { early Holocene }\end{array}$ & Undated & Undated \\
\hline Willow Garth & North Yorkshire & 512600 & 467600 & Bush \& Hall, 1987 & $\begin{array}{l}\text { Lateglacial Interstadial- } \\
\text { early Holocene }\end{array}$ & $\begin{array}{l}10985- \\
10615\end{array}$ & $9400-9160$ \\
\hline Wykeham Quarry & North Yorkshire & 498649 & 483101 & Lincoln et al., 2017 & $\begin{array}{l}\text { Dimlington Stadial-early } \\
\text { Holocene }\end{array}$ & $\begin{array}{l}15714- \\
14866\end{array}$ & $\begin{array}{l}11701- \\
11241\end{array}$ \\
\hline Whitrig Bog & $\begin{array}{l}\text { Southeast } \\
\text { Scotland }\end{array}$ & 362089 & 634797 & $\begin{array}{l}\text { Mayle et al., 1997; } \\
\text { Brooks \& Birks, } \\
2000\end{array}$ & $\begin{array}{l}\text { Lateglacial Interstadial- } \\
\text { Loch Lomond Stadial }\end{array}$ & $\begin{array}{l}12780- \\
12990\end{array}$ & $\begin{array}{l}11535- \\
12035\end{array}$ \\
\hline Creich Castle & East Scotland & 332900 & 721200 & $\begin{array}{l}\text { Cundill \& } \\
\text { Whittington, } 1983\end{array}$ & $\begin{array}{l}\text { Lateglacial Interstadial- } \\
\text { early Holocene }\end{array}$ & $\begin{array}{l}14080- \\
13240\end{array}$ & $9560-9150$ \\
\hline Abernethy Forest & East Scotland & 298377 & 818462 & $\begin{array}{l}\text { Matthews et al., } \\
2011 \text {; Brooks et } \\
\text { al., } 2012\end{array}$ & $\begin{array}{l}\text { Lateglacial Interstadial- } \\
\text { early Holocene }\end{array}$ & $\begin{array}{l}14505- \\
13790\end{array}$ & $\begin{array}{l}11135- \\
10735\end{array}$ \\
\hline Traeth Mawr & South Wales & 396700 & 225700 & Walker, 1982 & $\begin{array}{l}\text { Dimlington Stadial-early } \\
\text { Holocene }\end{array}$ & $\begin{array}{l}13370- \\
13730\end{array}$ & $\begin{array}{l}11315- \\
11715\end{array}$ \\
\hline Llanilid & South Wales & 294400 & 181800 & Walker et al., 2003 & $\begin{array}{l}\text { Dimlington Stadial- } \\
\text { Lateglacial Interstadial }\end{array}$ & $\begin{array}{l}16350- \\
14810\end{array}$ & $\begin{array}{l}13185- \\
12670\end{array}$ \\
\hline
\end{tabular}




\begin{tabular}{|c|c|c|c|}
\hline Depth (m OD) & Depth (m bgl) & Unit & Composition \\
\hline 50.64 to 50.48 & 0.00 to 0.16 & 14 & $\begin{array}{l}7.5 Y R \text { 4/2; As3 Ag 1; brown silty clay topsoil with modern } \\
\text { root material. Sharp contact to: }\end{array}$ \\
\hline 50.48 to 50.14 & 0.16 to 0.50 & 13 & $\begin{array}{l}\text { 7.5YR 4/3; As4 Ag+; brown clay with a trace of silt. } \\
\text { Diffuse contact to: }\end{array}$ \\
\hline 50.14 to 49.84 & 0.50 to 0.80 & 12 & $\begin{array}{l}2.5 \mathrm{Y} 5 / 2 \text { mottled } 2.5 \mathrm{Y} 6 / 4 \text {; As3 } \mathrm{Ag} 1 \text {; greyish brown silty } \\
\text { clay with light yellowish brown mottling. Diffuse contact } \\
\text { to: }\end{array}$ \\
\hline 49.84 to 49.36 & 0.80 to 1.28 & 11 & $\begin{array}{l}7.5 Y R \text { 5/1; As2 Ag2 Ga+; grey silt and clay with a trace } \\
\text { of sand. Sharp uneven contact to: }\end{array}$ \\
\hline 49.36 to 49.21 & 1.28 to 1.43 & 10 & $\begin{array}{l}7.5 \mathrm{YR} 2.5 / 1 \text {; Sh3 } \mathrm{Ag} 1 \mathrm{TI}+\text {; humo. } 3 / 4 \text {; black well } \\
\text { humified silty peat with pieces of detrital wood; paler } \\
\text { horizon at } 49.30-49.29 \mathrm{~m} \text { OD; vertical woody root } \\
\text { extends through the unit, truncated at upper contact. } \\
\text { Sharp contact to: }\end{array}$ \\
\hline 49.21 to 49.15 & 1.43 to 1.49 & 9 & $\begin{array}{l}7.5 \mathrm{YR} 4 / 1 \text {; As2 Ag2 } \mathrm{Dl}+\text {; brown silt and clay with pieces } \\
\text { of detrital wood; vertical woody root extends down from } \\
\text { overlying unit. Diffuse contact to: }\end{array}$ \\
\hline 49.15 to 49.12 & 1.49 to 1.52 & 8 & $\begin{array}{l}7.5 \mathrm{YR} 3 / 1 \text {; Sh2 Ga1 Ag1 Dl+; very dark grey very } \\
\text { organic silty sand with pieces of detrital wood; vertical } \\
\text { woody root extends down from overlying unit. Rare } \\
\text { Mollusca (mainly gastropods). Sharp contact to: }\end{array}$ \\
\hline 49.12 to 49.08 & 1.52 to 1.56 & 7 & $\begin{array}{l}2.5 \mathrm{Y} 7 / 2 ; \mathrm{Ag} 2 \mathrm{As} 2 \mathrm{Dl}+\text {; light grey calcareous clayey silt } \\
\text { with pieces of detrital wood; vertical woody root extends } \\
\text { down from overlying unit. Frequent Mollusca (mainly } \\
\text { gastropods). Diffuse contact to: }\end{array}$ \\
\hline 49.08 to 49.02 & 1.56 to 1.62 & 6 & $\begin{array}{l}\text { 7.5YR 4/2; Ag3 Ga1 } \mathrm{Dl}+\text {; brown sandy silt with pieces of } \\
\text { detrital wood; vertical woody root extends down from } \\
\text { overlying unit. Occasional Mollusca fragments. Sharp } \\
\text { contact to: }\end{array}$ \\
\hline 49.02 to 48.98 & 1.62 to 1.66 & 5 & $\begin{array}{l}\text { 7.5YR 4/1; As2 Ag1 Ga1 Dh+ Dl+; dark grey sandy silty } \\
\text { clay with a trace of detrital herbaceous material and } \\
\text { pieces of detrital wood; vertical woody root extends } \\
\text { down from overlying unit. Diffuse contact to: }\end{array}$ \\
\hline 48.98 to 49.95 & 1.66 to 1.63 & 4 & $\begin{array}{l}2.5 \mathrm{Y} 3 / 1 \text {; Gg3 As1 } \mathrm{Ag}+\text {; very dark grey silty clayey } \\
\text { gravel. Clasts are sub-angular to sub-rounded, } 5-20 \mathrm{~mm} \\
\text { in diameter; vertical woody root extends down from } \\
\text { overlying unit. Diffuse contact to: }\end{array}$ \\
\hline 48.95 to 48.92 & 1.63 to 1.60 & 3 & $\begin{array}{l}2.5 \mathrm{Y} 3 / 1 \text {; As2 } \mathrm{Ag} 2 \mathrm{Dh}+\text {; very dark grey silty clay with a } \\
\text { trace of detrital herbaceous material; vertical woody root } \\
\text { terminates downward within unit. Diffuse contact to: }\end{array}$ \\
\hline 48.92 to 48.89 & 1.63 to 1.75 & 2 & $\begin{array}{l}2.5 \mathrm{Y} 3 / 1 \text {; Gg2 As1 } \mathrm{Ag} 1 \mathrm{Dh}+\text {; very dark grey silty clayey } \\
\text { gravel with a trace of detrital herbaceous material. } \\
\text { Diffuse contact to: }\end{array}$ \\
\hline 48.89 to 48.77 & 1.75 to 1.87 & 1 & $\begin{array}{l}\text { 7.5YR 4/3; Gg2 Ga1 Ag1; brown silty sandy gravel. } \\
\text { Clasts are sub-angular to sub-rounded, } 5-20 \mathrm{~mm} \text { in } \\
\text { diameter. }\end{array}$ \\
\hline
\end{tabular}


Table 3: Results of the waterlogged wood identifications at Turker Beck.

\begin{tabular}{|c|c|c|c|c|c|}
\hline $\begin{array}{l}\text { Depth (m } \\
\text { OD) }\end{array}$ & Unit & Identification & $\begin{array}{l}\text { Common } \\
\text { name }\end{array}$ & Quantity & Comments \\
\hline \multirow[t]{2}{*}{$49.39-49.34$} & 11 & Alnus sp. & alder & 8 & $\begin{array}{l}x 7=\text { twig-wood } \varnothing \\
<6 \mathrm{~mm} ; \mathrm{x} 1=\text { round- }\end{array}$ \\
\hline & & Indeterminate & - & 2 & $\begin{array}{l}\text { wood } \varnothing \text { ca. } 16 \mathrm{~mm} \\
\text { x2 = twig-wood } \varnothing \\
<3 \mathrm{~mm} \text {. (unknown } \\
\text { hardwood) }\end{array}$ \\
\hline $49.29-49.24$ & 10 & Alnus sp. & alder & 10 & $\begin{array}{l}x 3=\text { twig-wood } \varnothing \\
<5 \mathrm{~mm} ; x 7=\text { round- } \\
\text { wood } \varnothing>9 \mathrm{~mm}\end{array}$ \\
\hline $49.26-49.24$ & 10 & $\begin{array}{l}\text { Alnus sp. } \\
\text { Salix/Ponulus sn }\end{array}$ & $\begin{array}{l}\text { alder } \\
\text { willow/nonlar }\end{array}$ & $\begin{array}{l}4 \\
1\end{array}$ & Twig wood \\
\hline $49.19-49.14$ & $8 / 9$ & Alnus sp. & alder & 13 & $\begin{array}{l}\times 2=\text { twig-wood } \varnothing \\
<7 \mathrm{~mm} ; x 8=\text { round- } \\
\text { wood } \varnothing<15 \mathrm{~mm}\end{array}$ \\
\hline $49.15-49.14$ & 8 & $\begin{array}{l}\text { Betulaceae } \\
\text { (Alnus/Betula } \\
\text { type) }\end{array}$ & $\begin{array}{l}\text { alder/birch } \\
\text { type }\end{array}$ & 1 & - \\
\hline $49.14-49.12$ & 8 & $\begin{array}{l}\text { Alnus sp. } \\
\text { Indeterminate }\end{array}$ & $\begin{array}{l}\text { alder } \\
-\end{array}$ & $\begin{array}{l}4 \\
5\end{array}$ & $\begin{array}{l}\text { Twig wood } \\
\text { Hardwood }\end{array}$ \\
\hline $49.12-49.07$ & $6 / 7$ & $\begin{array}{l}\text { Alnus sp. } \\
\text { Salix/Populus sp. } \\
\text { Indeterminate }\end{array}$ & $\begin{array}{l}\text { alder } \\
\text { willow/poplar } \\
\text { - }\end{array}$ & $\begin{array}{l}8 \\
1 \\
1\end{array}$ & $\begin{array}{l}\text { Twig wood } \\
\text { Twig wood } \\
\text { Hardwood }\end{array}$ \\
\hline $49.09-49.04$ & $6 / 7$ & Alnus sp. & alder & 11 & $\begin{array}{l}x 3=\text { twig-wood } \varnothing \\
<6 \mathrm{~mm} ; x 7=\text { round- } \\
\text { wood } \varnothing<13 \mathrm{~mm}\end{array}$ \\
\hline
\end{tabular}


Table 4: Results of the insect analysis of bulk samples $<1>,<3>,<5>$ and $<7>$ at Turker Beck, showing the minimum number of individuals of each taxon.

\begin{tabular}{|c|c|c|c|c|}
\hline \multirow[b]{2}{*}{ Taxon } & \multicolumn{4}{|c|}{ Bulk sample (depth m OD) } \\
\hline & $\begin{array}{c}<1> \\
(49.39- \\
49.34)\end{array}$ & $\begin{array}{c}<3> \\
(49.29 \\
49.24)\end{array}$ & $\begin{array}{c}<5> \\
(49.19- \\
49.14)\end{array}$ & $\begin{array}{c}<7> \\
(49.09- \\
49.04)\end{array}$ \\
\hline \multicolumn{5}{|l|}{ Dytiscidae } \\
\hline Hydroporus sp. & 1 & & & \\
\hline Agabus sp. & & & 1 & \\
\hline \multicolumn{5}{|l|}{ Carabidae } \\
\hline Leistus spinibarbis (F.) & & & 1 & \\
\hline Dyschirius aeneus Dej. & & & & 1 \\
\hline Patrobus atrorufus (Störm) & & 2 & 1 & \\
\hline $\begin{array}{l}\text { Trechus quadristriatus } \\
\text { (Schrank.) }\end{array}$ & & & 1 & \\
\hline Trechus rivularis (Gyll.) & & & & 2 \\
\hline Trechus rubens (F.) & & 1 & & \\
\hline Bembidion doris (Panz.) & & & & 1 \\
\hline Bembidion obscurellum (Mots.) & & & & 1 \\
\hline Bembidion spp. & & & 2 & \\
\hline Pterostichus nigrita (Payk.) & & & & 1 \\
\hline Pterostichus vernalis (Panz.) & & & & 1 \\
\hline Pterostichus spp. & & & 1 & 1 \\
\hline Agonum thoreyi (Dej.) & & 1 & & \\
\hline Dromius quadrimaculatus (L.) & & & 1 & \\
\hline \multicolumn{5}{|l|}{ Helophoridae } \\
\hline Helophorus grandis III. & & & 3 & \\
\hline Helophorus obscurus (Muls.) & & & 2 & 1 \\
\hline Helophorus spp. & 1 & 1 & & \\
\hline \multicolumn{5}{|l|}{ Hydrophilidae } \\
\hline Enochrus sp. & & & 1 & \\
\hline Laccobius sp. & & & 1 & 1 \\
\hline Cercyon bifenestratus (Kust.) & & & & 1 \\
\hline Cercyon marinusThoms. & & 2 & 1 & 1 \\
\hline Cercyon sp. & 1 & & 1 & \\
\hline \multicolumn{5}{|l|}{ Histeridae } \\
\hline Margarinotus margarinatus (Er.) & & & 1 & \\
\hline \multicolumn{5}{|l|}{ Hydraenidae } \\
\hline Hydraena palustris (Er.) & & 1 & 1 & 2 \\
\hline Ochthebius minimus (Fab.) & & 1 & 2 & 2 \\
\hline \multicolumn{5}{|l|}{ Staphylinidae } \\
\hline Acidota crenata (Fab.) & & 1 & & 1 \\
\hline Arpedium quadrum (Er.) & 1 & & 4 & 2 \\
\hline Lesteva punctana (Er) & & & & 1 \\
\hline Olophrum fuscum (Grav) & & 1 & 3 & \\
\hline Olophrum sp. & & 1 & & \\
\hline Lordithon thorasicus (Fab) & & 1 & & \\
\hline
\end{tabular}




\begin{tabular}{|c|c|c|c|c|}
\hline \multirow[b]{2}{*}{ Taxon } & \multicolumn{4}{|c|}{ Bulk sample (depth m OD) } \\
\hline & $\begin{array}{c}<1> \\
(49.39- \\
49.34)\end{array}$ & $\begin{array}{c}<3> \\
(49.29- \\
49.24)\end{array}$ & $\begin{array}{c}<5> \\
(49.19- \\
49.14)\end{array}$ & $\begin{array}{c}<7> \\
(49.09- \\
49.04)\end{array}$ \\
\hline Tachinus laticollis (Grav.) & & 1 & & \\
\hline Atheta spp. & & & 2 & 1 \\
\hline Stenus spp. & & & 2 & 2 \\
\hline Lathrobium sp. & & & 2 & \\
\hline Quedius spp. & & & & 2 \\
\hline \multicolumn{5}{|l|}{ Scirtidae } \\
\hline Cyphon padi (L.) & & 1 & 1 & \\
\hline \multicolumn{5}{|l|}{ Byrrhidae } \\
\hline Cytilus sericeus (Forst.) & & & 1 & 1 \\
\hline \multicolumn{5}{|l|}{ Elmidae } \\
\hline Esolus parallelepipedus (Müller) & & & 1 & \\
\hline \multicolumn{5}{|l|}{ Chrysomelidae } \\
\hline Donacia simplex (Fab.) & & & 1 & \\
\hline Donacia sparganii (Ahrens) & & & 1 & \\
\hline \multicolumn{5}{|l|}{ Plateumaris discolor (Panz.) } \\
\hline Galeruca sp. & & & 1 & \\
\hline \multicolumn{5}{|l|}{ Curculionidae } \\
\hline Limnobaris t-album (L.) & & 1 & & \\
\hline Tanysphyrus lemnae (Payk.) & & & 1 & 2 \\
\hline
\end{tabular}


Table 5: Results of the radiocarbon dating of samples from column $<1>$ (Trench 1) at Turker Beck, calibrated using OxCal v4.3.2 (Bronk Ramsey, 2017) and the IntCal13 calibration curve (Reimer et al., 2013).

\begin{tabular}{|c|c|c|c|c|c|c|c|}
\hline $\begin{array}{l}\text { Laboratory code / } \\
\text { Method }\end{array}$ & $\begin{array}{l}\text { Depth } \\
\text { (m OD) }\end{array}$ & Unit & Material & $\begin{array}{l}\text { Radiocarbon } \\
\text { age (a BP) }\end{array}$ & 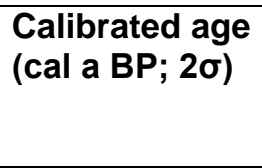 & $\delta 13 \mathrm{C}(\% 0)$ & $\begin{array}{l}\text { Outlier model } \\
\text { posterior } \\
\text { probability } \\
(\%)\end{array}$ \\
\hline $\begin{array}{l}\text { SUERC-49861 } \\
(\text { GU32531)* }\end{array}$ & $49.99-49.98$ & $\begin{array}{l}\text { Equivalent to upper } \\
\text { part of Unit 8? }\end{array}$ & $\begin{array}{l}\text { 'Vegetation and leaf } \\
\text { fragments' }\end{array}$ & $10390 \pm 47$ & $12385-12295$ & -28.9 & $\mathrm{~N} / \mathrm{A}$ \\
\hline $\begin{array}{l}\text { SUERC-49860 } \\
(\text { GU32530)* }\end{array}$ & 49.73-49.72 & $\begin{array}{l}\text { Equivalent to lower } \\
\text { part of Unit 8? }\end{array}$ & 'Moss' & $12270 \pm 56$ & $14275-14165$ & -33.7 & $N / A$ \\
\hline $\begin{array}{l}\text { SUERC-54713 } \\
(\text { GU34716) }\end{array}$ & $49.23-49.21$ & 10 & Twig wood & $4384 \pm 29$ & $5040-4870$ & -28.3 & $N / A$ \\
\hline $\begin{array}{l}\text { SUERC-81422 } \\
\text { (GU48662) }\end{array}$ & $49.15-49.14$ & 8 & Alnus sp. twig & $12260 \pm 25$ & $14295-14045$ & -28.9 & 4 \\
\hline $\begin{array}{l}\text { SUERC-54714 } \\
\text { (GU34717) }\end{array}$ & $49.14-49.12$ & 8 & Twig wood & $12374 \pm 30$ & $14700-14160$ & -28.5 & 3 \\
\hline BETA-396040 & $49.14-49.12$ & 8 & Salix/Populus sp. twig & $12190 \pm 40$ & $14155-14000$ & -28.6 & 4 \\
\hline BETA-396039 & $49.12-49.07$ & 7 & Alnus sp. twig & $12310 \pm 40$ & $14340-14120$ & -28.6 & 3 \\
\hline
\end{tabular}

${ }^{*}$ Radiocarbon dates from Rackham \& Clay (2014) (not included in the P_Sequence age-depth model)

${ }^{* *}$ Not included in the $P$ _Sequence age-depth model. 


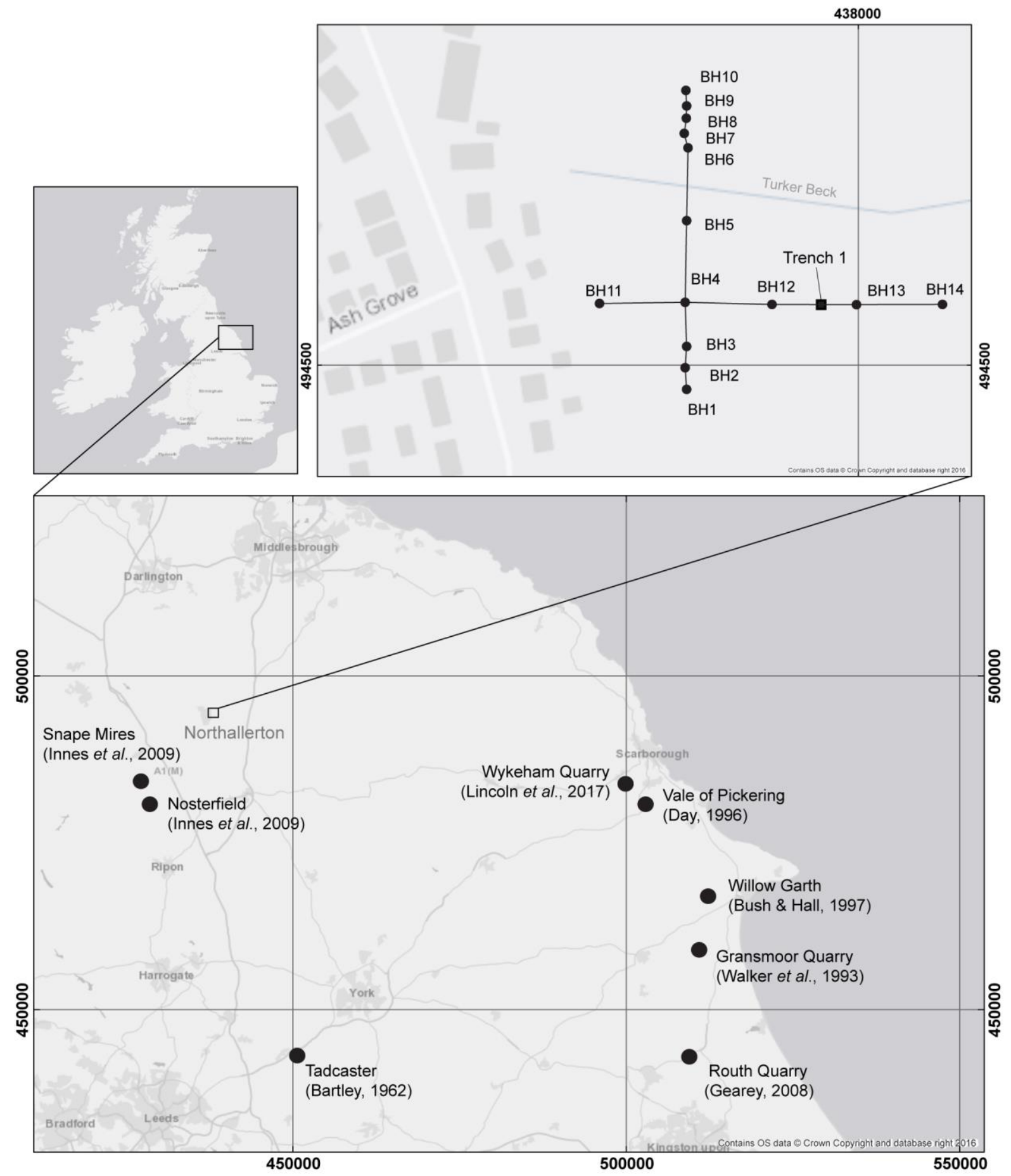

Figure 1: Location of the site at Turker Beck, Northallerton, North Yorkshire, showing previous geoarchaeological boreholes and Trench 1 (from which column sample $<1>$ and a series of bulk samples were obtained). Other Lateglacial Interstadial sequences mentioned in the text are also shown. 

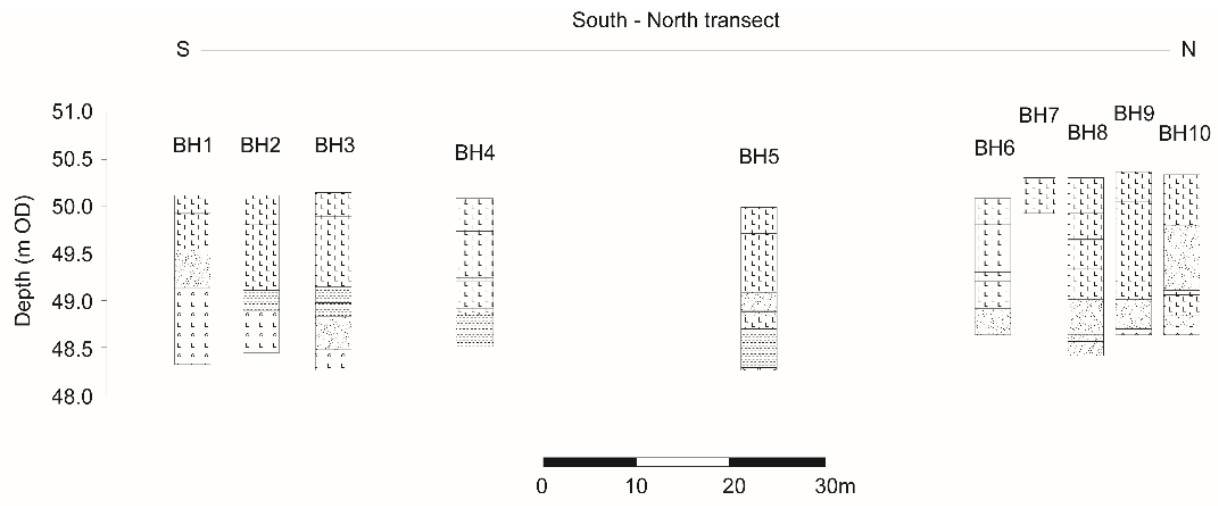

W

West - East transect

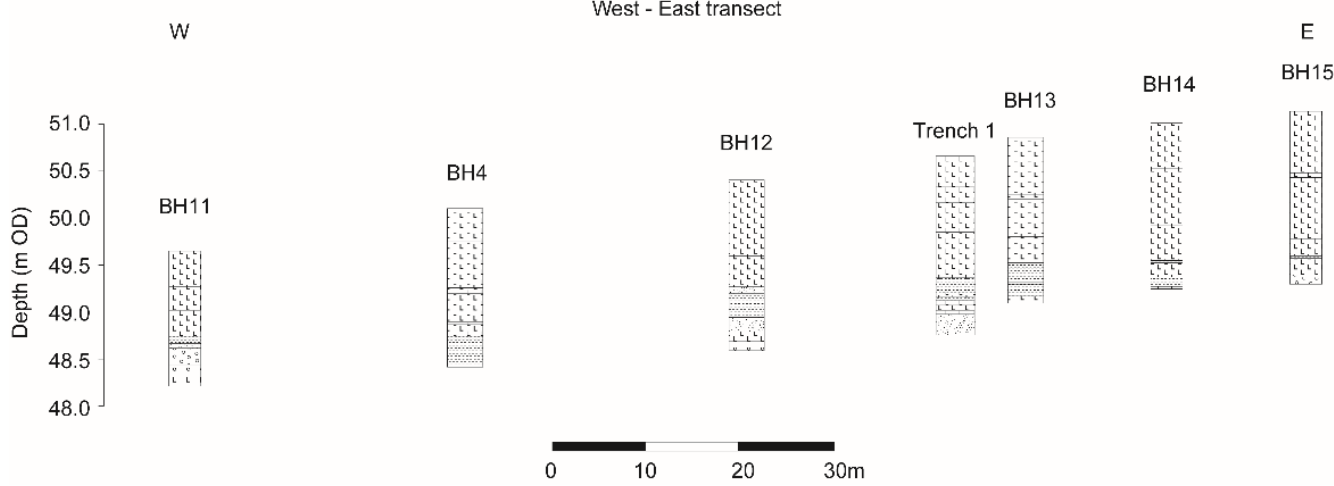

Figure 2: Lithostratigraphy of the previous geoarchaeological boreholes and Trench 1 (East-West and North-South transects) at Turker Beck. 


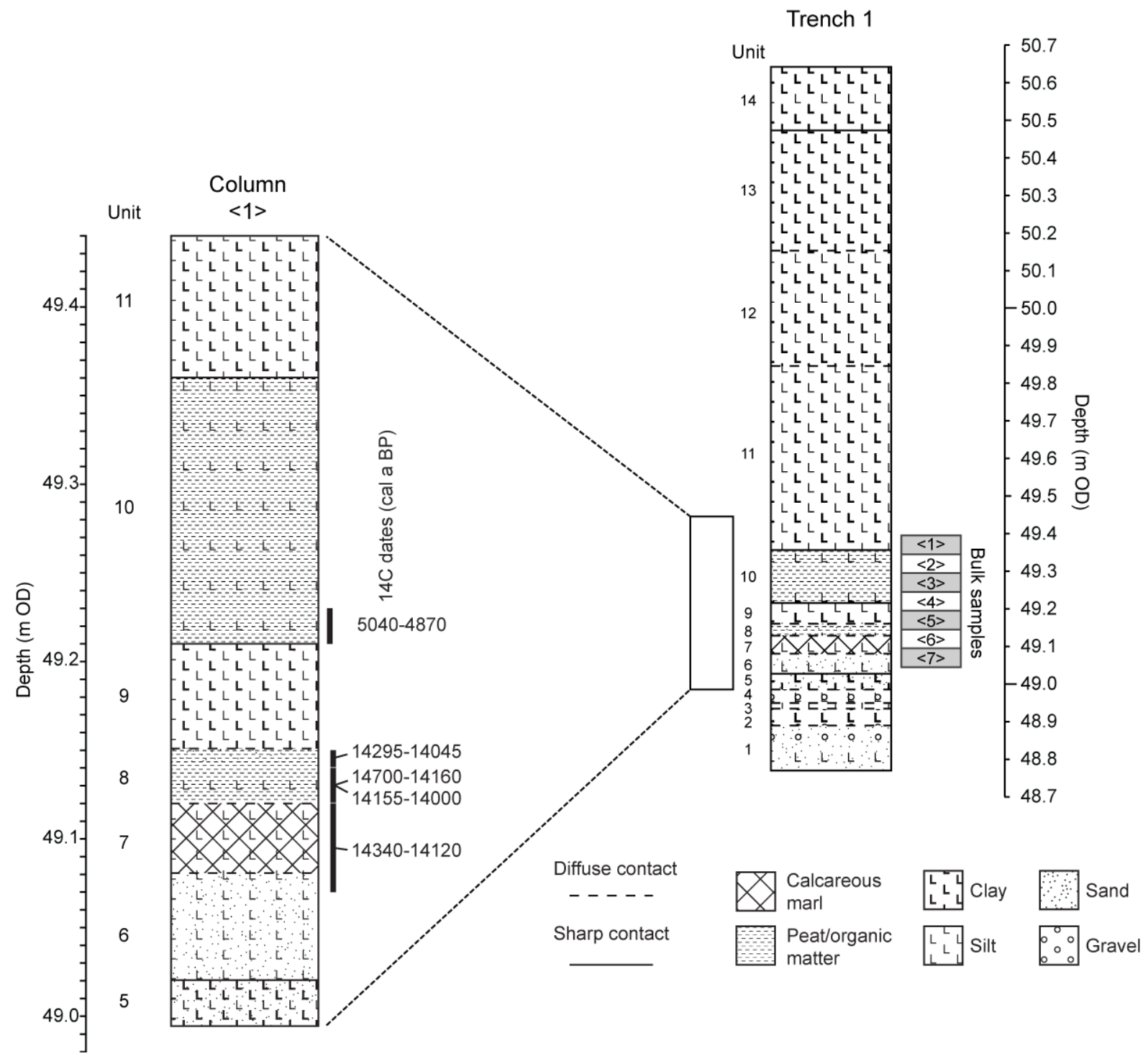

Figure 3: Lithostratigraphy of Trench 1 and Column $<1>$ at Turker Beck, showing the results of the radiocarbon dating and the location of Column $<1>$ and bulk samples $<1>$ to $<7>$. 

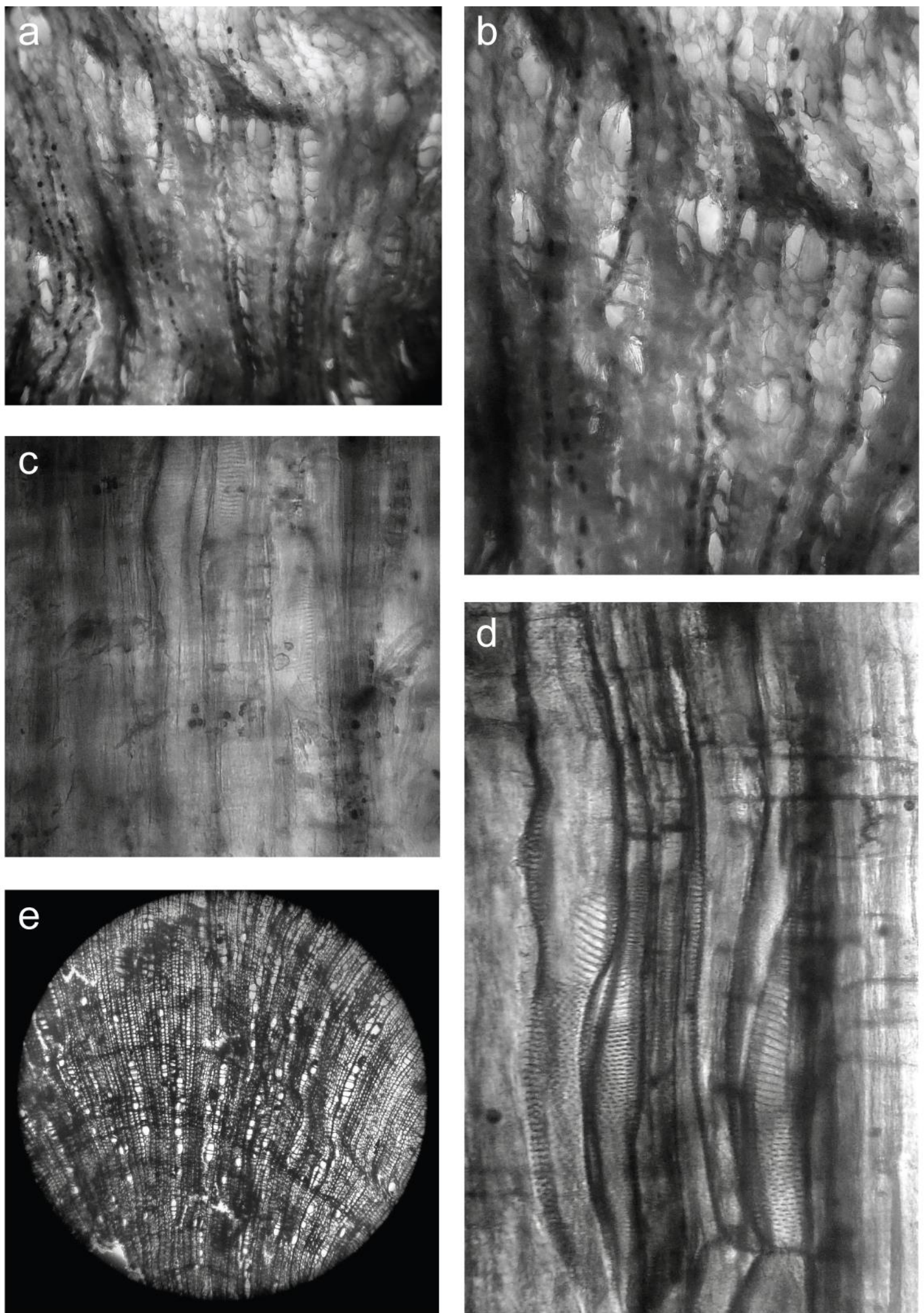

Figure 4: Thin sections of selected wood macrofossils identified as Alnus sp.: a) transverse section (TS) of cf. Alnus sp. from 49.15-49.14m OD showing pore arrangement; b) TS of cf. Alnus sp. from 49.15-49.14m OD showing pore arrangement; c) radial section (RLS) of cf. Alnus sp. from 49.15-49.14m OD showing scalariform perforation plates; d) RLS (x200) of Alnus sp. from 49.0949.04m OD showing scalariform perforation plates; e) TS (x50) Alnus sp. pore arrangement and growth rings. 


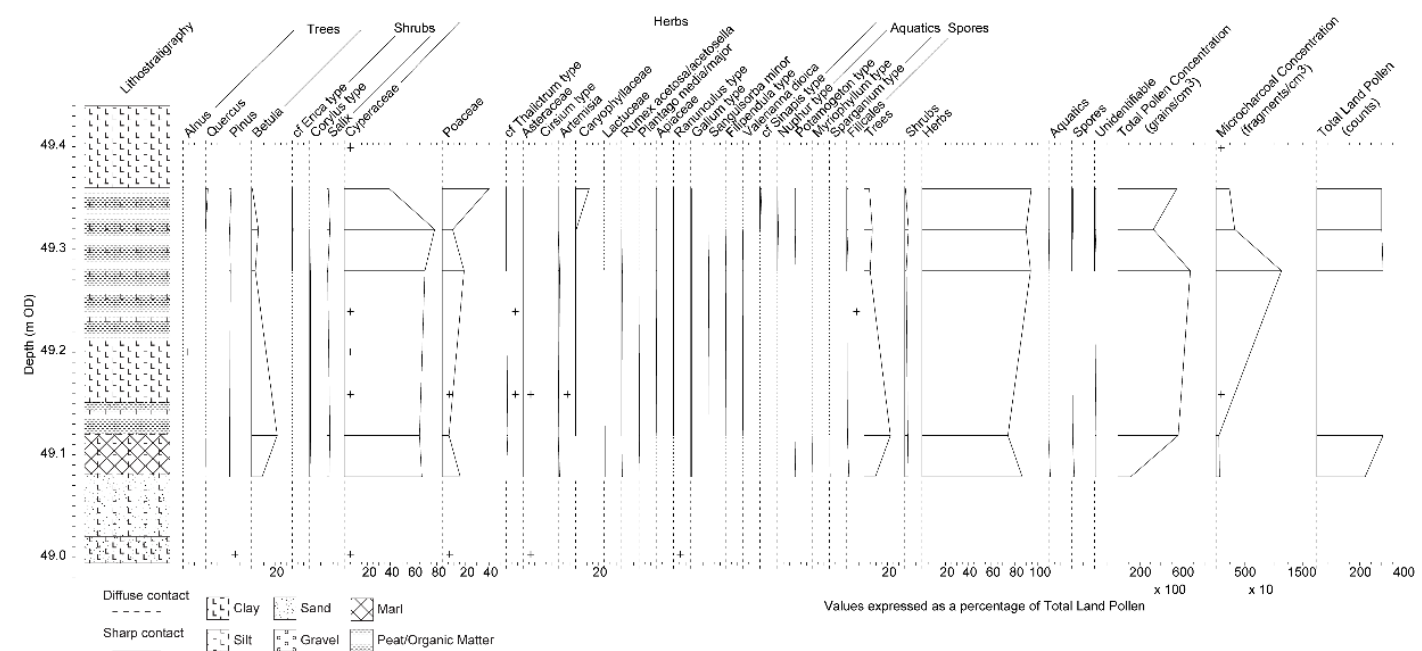

Figure 5: Results of the pollen analysis of samples from Column $<1>$, Turker Beck. Lithostratigraphy of the sequence also shown.

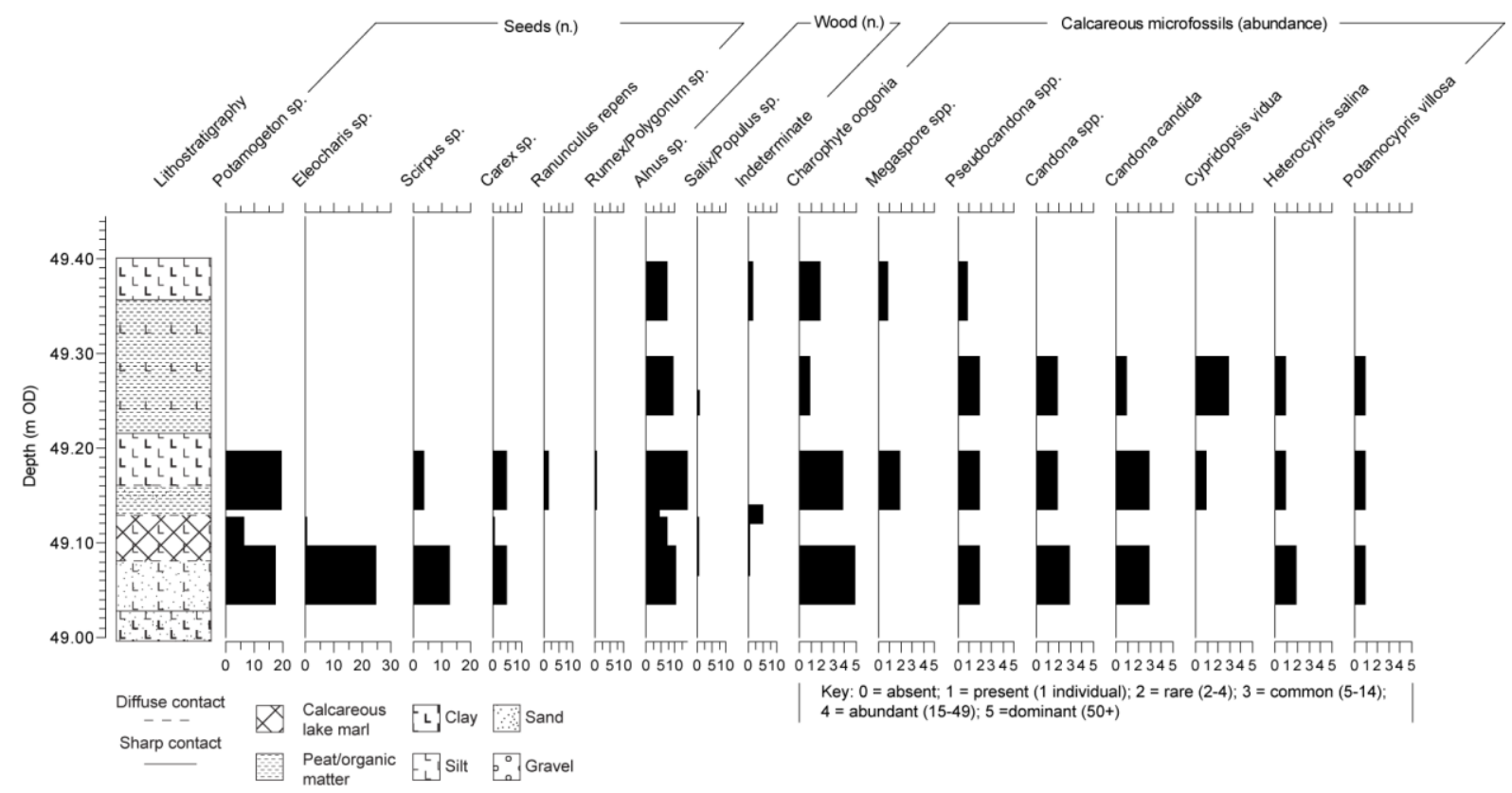

Figure 6: Results of the plant macrofossil analysis (waterlogged seeds and wood) and calcareous microfossil assessment of samples from Turker Beck. Lithostratigraphy of the sequence also shown. 


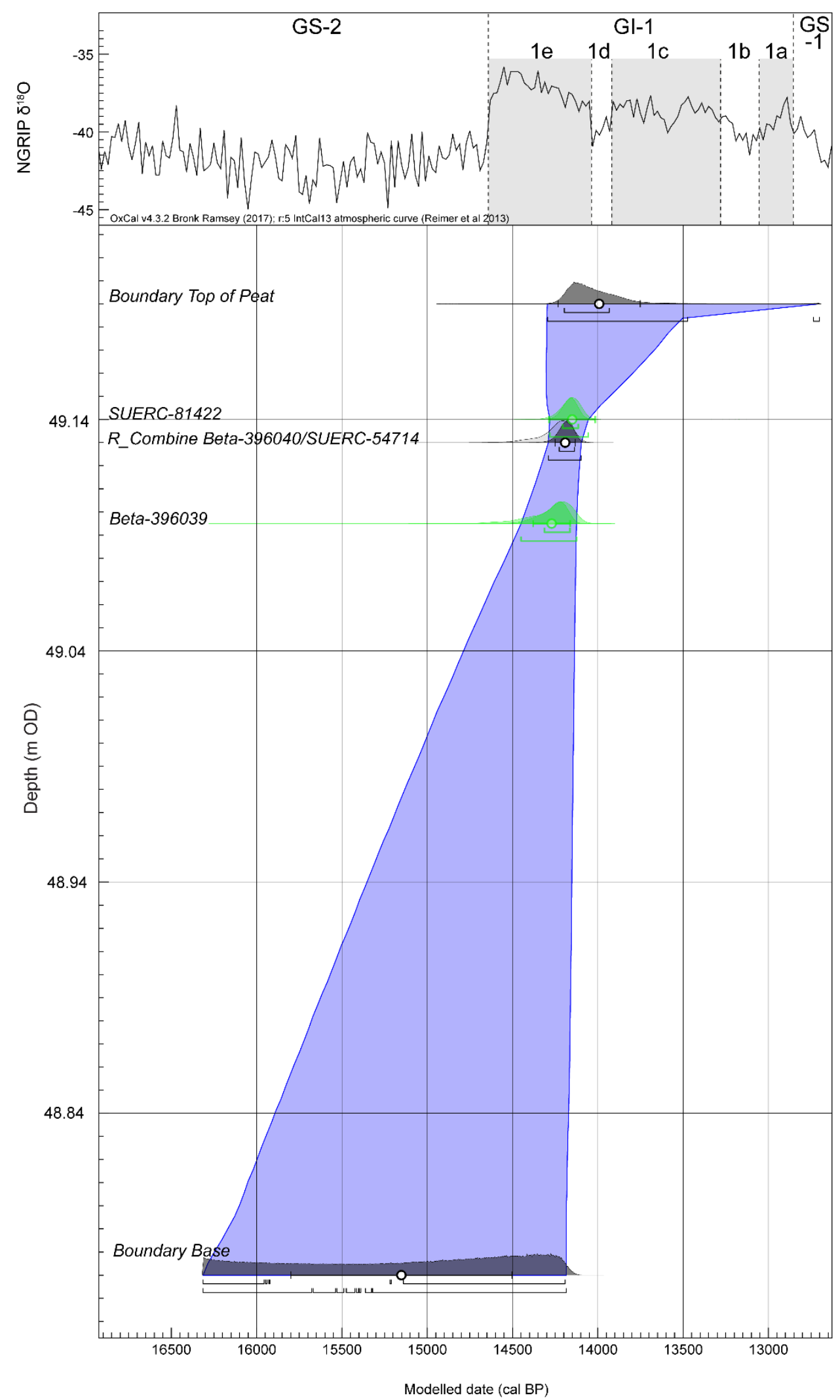

Figure 7: Bayesian 'P_Sequence' age-depth model for the part of the sequence from which Lateglacial dates have been obtained at Turker Beck, produced using OxCal version 4.3.2 (Bronk Ramsay, 2017) and the IntCal13 calibration curve (Reimer et al., 2013). Dark blue shading shows the limit of the $95.4 \%$ probability ranges. NGRIP $\delta^{18} \mathrm{O}$ (\% VSMOW) for the corresponding period from Rasmussen et al. (2016) shown for reference. 